\title{
An Empty Shell
}

Divergent opinions existed among the ISH leadership about the fate of the organisation after the December 1933 meeting in Moscow. Ernst Wollweber interpreted the instructions as a downscaling of activities and a way for merging the ISH with the ITF. ${ }^{1}$ Adolf Shelley, on the other hand, regarded the instructions not as a masterplan for an amalgamation but a guide for developing the activities of the ISH. In his mind, the ISH sections and the revolutionary trade union opposition within the ITF-affiliated unions were to be strengthened, and he therefore outlined a blueprint of actions to be taken in early 1934, see Table $13 .^{2}$

Shelley's basic idea was the adaption of a double strategy. In line with the December 1933 Resolution and the "Confidential instructions", focus was on strengthening the opposition within ITF-affiliated unions, such as the NUs in England, and 'reformist'-controlled ones, such as those in Brazil, Ireland and Mexico. However, in other countries, such as Argentina, Australia, New Zealand, and Scotland, the unions were to affiliate with the ISH. The plan put a heavy focus on invigorating work in South and Central America; instructors were to be deployed to boost activities and to investigate the possibilities for organising Interclubs in Havana, Montevideo, Rosario, Santos, Valparaiso and Vera Cruz. ${ }^{3}$ Shelley's masterplan outlined the Interclubs as key nodes of agitation and propaganda. Therefore, he projected the establishment or reorganising of them in Antwerp, Barcelona, Bratislava, Cardiff, Constanza, Danzig (the existing one seems to have been closed in 1933), Durban, Narvik, New Orleans (the existing one was dysfunctional already in $1933^{4}$ ), North and South Shields, Piraeus, Shanghai, Sydney (the existing one seems to have ceased operations in 1931/32), Thessaloniki, and Vancouver. There was only one practical

1 Wollweber, Lebenserinnerungen, 153, 155, Nachlass Ernst Wollweber, NY4327/10, BArchB.

2 Stolarski [Shelley] to the RILU Secretariat, 2.1.1934, 534/5/241, 6-7, RGASPI.

3 Plan to reorganise and strengthen the ISH and the revolutionary opposition, February 1934, $534 / 5 / 236,178-179$, RGASPI. The document is an unsigned draft although combined with Shelley's letter to the RILU Secretariat, I assume that it either heavily reflected his ideas or had been drafted by him.

4 As reported by Everett to 'Dear Comrades,' 11.2.1933, 534/7/509, 83, RGASPI: "The hall was lost when the comrades could not pay the rent here. They moved into a place which served them as a combined hall and a place to sleep." 
TABLE 13 Plan to reorganise and strengthen the ISH and the revolutionary opposition, February 1934

Canada

Australia

New Zealand

England

Scotland

France

USA

Brazil

Chile

Argentina
To create a strong central leadership of the Marine Workers' League (the Is H section in Canada) and by concentrating the activity of the League on three points: in Montreal, Vancouver, and the Great Lakes To charge the Minority Movement with the task of winning over the leadership of the seamen's union and harbour workers' union and affiliating them with the Is $\mathrm{H}$ To strengthen the opposition movement within the seamen's union as well as the harbour workers' union for the purpose of affiliating the union to the IS $\mathrm{H}$ To strengthen the revolutionary opposition within the NUs; to appoint a colonial committee at the Liverpool Interclub for work among Indonesian, Indian, Chinese and black seamen; to organise the union of Indian seamen in London to be headed by "comrade G" and to organise systematic work on the ships among Indian crews

To win over the leadership of the harbour workers' union in Glasgow and affiliate it with the Is $\mathrm{H}$

To reorganise the Interclub in Marseille as well as to establish new Interclubs with the assistance of the PCF in Dunkirk, Le Havre and Oran

To strengthen the opposition within the International Association of Harbor Workers and the International Seamen's Union; to concentrate work to New York, New Orleans, San Francisco and the Great Lakes as well as to Boston, Norfolk, Philadelphia and Seattle

To strengthen the revolutionary trade union opposition within the seamen's union and harbour workers' union in Rio de Janeiro and Santos

To prepare the convocation of a national unity conference for setting up a national marine workers' organisation

To place a representative of the ISH in the leadership of the FOM and to separate FOM unions and propose to set up contacts with the Is $\mathrm{H}$ 
TABLE 13 Plan to reorganise and strengthen the ISH and the revolutionary opposition, February 1934 (cont.)

Uruguay

Cuba

Mexico

Indonesia

Ireland
To call a unity conference for the purpose of uniting all existing craft unions and for organising a single industrial union

To organise a revolutionary trade union opposition and to call for a unity conference

To strengthen the revolutionary trade union opposition in all existing unions

To strengthen work among Indonesian seamen in

Rotterdam, Liverpool and New York; to set up strong contacts from Singapore with the seamen and harbour workers of Indonesia proper

To shift the gravity of work among seamen to the reformist seamen's union as well as to establish a united front of harbour workers in Ireland

SOURCE: PLAN TO REORGANISE AND STRENGTHEN THE ISH AND THE REVOLUTIONARY OPPOSITION, FEBRUARY 1934, 534/5/236, 172-180, RGASPI

problem - cash - but Shelley was confident that the RILU would provide extra funding for the (re-)establishment of the global network of Interclubs. ${ }^{5}$

However, Shelley overestimated the capability and capacity of the ISH to emerge as a global player. His own assessment on the achievements and organisational strength of the ISH and its sections must have been disappointing reading in Moscow. Almost nothing of its earlier global outreach existed anymore in early 1934. Data on most national sections was missing, indicating that they either had ceased to function or had dysfunctional connections with the IS H headquarters; see Table $14{ }^{6}$

5 Stolarski [Shelley] to the RILU Secretariat, 2.1.1934, 534/5/241, 6-7, RGASPI.

6 Material über die ISH und über die Arbeit unter den Seeleuten und Hafenarbeitern, 20.1.1934, $534 / 5 / 241,74-88$, RGASPI. The author of the unsigned document was someone at the ISH Secretariat as is revealed by the dense information on the situation in France, England, USA and the Scandinavian countries as well as the plan (and failure) to intervene at the congress of the Finnish Seamen's Union in December 1933. Especially the information on the Latvian seamen's strike ("begegnete ich in Kopenhagen Gen. Lambert" as well as "das Sekretariat der ISH in meiner Person") suggests Shelley to be the author of the document as Wollweber, at this point, did, not reside in Copenhagen anymore. 
TABLE 14 Organisations and opposition groups affiliated to the ISH, January 1934

Country/Organisation

England: SMM (mainly in Liverpool)

USA: MWIU

Japan: Sasinkai

France: FUMP

Germany: Einheitsverband (illegal)

Spain: Seville

Spain: others (Vera Cruz de Las Palmas, Gijon,

San Sebastian, Barcelona)

Italy: FILM (illegal)

Greece

Danzig

Latin America

South Africa: Durban

Southwest Africa: fishermen's association in

Lüderitz Bay

China: European bureau in Rotterdam

Poland: majority of seamen's union incl.

leadership

Latvia: majority of seamen's union incl.

leadership

Denmark: one third of seamen's union and

9o percent of stokers' union

Sweden: Sjötransportarbetarnas RFO

Norway: six local branches of RFO

Australia: seamen's union

\section{Membership}

600

3000

Not known

4500 (1 800 paying

members)

(previously 10 ooo), 2800

paying members

3600

$[\ldots]$

$[\ldots]$

$[\ldots]$

[...]

[...]

[...]

[...]

400

[...]

[..]

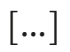

1200

[...]

[...]

SOURCE: MATERIAL ÜBER DIE ISH UND ÜBER ARBEIT UNTER DEN SEELEUTEN UND HAFENARBEITER, 20.1.1934, 534/5/241, 70-88, RGASPI

Shelley's report indicated that the direct outreach of the IS H was restricted to Northern and Western Europe. The best functioning section was the Danish one, i.e. the Danish Stokers' Union. Positive results had been achieved in Estonia and Latvia, and the position of the revolutionary trade union opposition was 
relatively strong in Sweden and the Netherlands. However, he had to admit that the general outlook was pathetic, especially in the USA and England. Cooperation with the PCF and the CGTU was bad in France; in Spain, the red union in Barcelona was in a state of agony. The only positive news was the situation in Australia where the majority of the seamen's union had voted to nominate an adherent of the ISH as general secretary ${ }^{7}$. The most revealing part of Shelley's report was his total silence about work among colonial seamen not a single line, perhaps indicating that it more or less had ceased to exist? ${ }^{8}$

What existed was an empty shell. The global network of Interclubs had retracted into a mainly North Atlantic-Scandinavian one, see Table 15.

Moscow, for certain, was not impressed by the achievements of the ISH. Even though the RILU leadership might have wanted to revitalise the ISH, the situation in Moscow effectively nullified any such aspirations as the Comintern headquarters and its apparatus was undergoing a total overhaul. Following the reorganisations during autumn 1933, all work was concentrated to a Ländersekretariat or regional office of the ECCI. ${ }^{9}$

Even more drastic was the reorganisation of the RILU apparatus. The blueprint for the total revision of the RILU apparatus had been initiated already in July 1933. Its central unit, the Sekretariat der Interkoms (Secretariat of the International Committees), was abolished and most of the International Committees, i.e., the former International Propaganda and Action Committeres,

7 This was Joseph "Joe" Keenan who sojourned in England as ISH representative in 1933. He was reported to have arrived in Copenhagen in October 1933, and the ISH leadership proposed to send him via Vladivostok and Singapore to Australia "as there is a good chance for him to be elected secretary for the Australian union." (Note/Memorandum to "Lieber Freund," [Copenhagen] 28.10.1933, 534/5/236, 124, RGASPI. The author of the memo was most likely Schmidt/Wollweber.) Keenan was still in Europe (Copenhagen or Moscow?) in January/February 1934 as is indicated in Shelley's plan for future work of the ISH ("Keenan to be sent to Australia and New Zealand"). He arrived in Australia in October 1934, rejoined the Seamen's Union of Australia, immediately emerged as the leader of its communist fraction and was one of the key organisers during the Australian seamen's strike in 1935, see further Louis, "Recovery from Depression and the Seamen's Strike 1935-6," and Donald Sinclair Fraser, Articles of agreement: the Seamen's Union of Australia, 1904-1943 a study of antagonized labour, PhD thesis, Department of History and Politics, University of Wollongong, 1998, 171. Interestingly, the ISH Secretariat did not launch an international campaign in support of the Australian mariners, or at least it did not refer to it in its correspondence with Moscow.

8 Material über die ISH und über die Arbeit unter den Seeleuten und Hafenarbeitern, 20.1.1934, 534/5/241, 74-88, RGASPI.

9 (Memorandum, translated from Russian) The Reorganisation of the Apparatus of the Comintern. (Confirmed by the Polit Commission Sept. 15, 1933), Appendix to Protokoll (A) Nr. 334 der Sitzung der Politkommission des Pol.Sekr. des EKKI, 15.9.1933, 495/4/261, 114-117, RGASPI. 
TABLE 15 Interclubs and "liaison centres" of the ISH, January 1934

Country

A. Interclubs

Denmark

Netherlands

Spain

Uruguay

USA

Soviet Union

\section{B. Liaison centres/offices of call (Anlaufstellen)}

Belgium

United Kingdom

France

Antwerp

Gent

Liverpool

Belfast

\section{Location}

Copenhagen

Esbjerg

Aalborg

Bergen

Oslo

Tromsø

Haugesund

Stockholm

Stugsund

Gävle

Sundsvall

Malmoe

Rotterdam

Seville

Montevideo

New York

Philadelphia

Baltimore

Boston

New Orleans

San Francisco

Portland

Seattle

"in all ports"

North Shields

South Shields

Strasbourg

Marseille

Rouen 
TABLE 15 Interclubs and "liaison centres" of the ISH, January 1934 (cont.)

Country Location

\begin{tabular}{ll}
\hline & Dunkirk \\
Switzerland & Basle \\
Spain & Barcelona \\
South Africa & Durban \\
Australia & Sydney \\
\hline
\end{tabular}

SOURCE: LIST OF INTERCLUBS AND "ANLAUFSTELLEN," PUBLISHED IN INFORMATIONSBULLETIN DER I.S.H. DEUTSCHE AUSGABE 4:1 (JANUAR 1934), 495/20/858, 31, RGASPI

were subordinated to the regional offices (Ländersekretariat) of the RILU. The RILU Organisational Department, too, was liquidated and its tasks were transferred to the regional offices of the RILU. ${ }^{10}$

The RILU headquarters decided to stick to its original masterplan for organising future work among maritime transport workers. Following the decisions of the XIII ECCI Plenum, the RILU sent instructions to establish a special Initiative Committee to call for an international conference of the ITFopposition groups and unions. As outlined by the Commission for work among seamen, the Initiative Committee was to include both maritime and land transport workers' unions. Those listed were the Danish Stoker's Union, the Gothenburg and Stockholm branches of the Swedish Seamen's Union, local branches of the English Railway Workers' Union, the Irish Railway Workers' Union, the Czechoslovakian Railway Workers' Union, and the (illegal) German Transport Workers' Federation. However, in contrast to the draft version of the 'Confidential instructions', the RILU declared a truce on the propaganda front: Neither the ISH nor the International Trade Union Committee for Railway Workers were to attack the ITF during the campaign for the international conference. Most important, and directly affecting Shelley's ambitions, was the strict order to restrain from any activities to extend the organisational basis of the ISH. Instead, it instructed the IS H Secretariat to keep a low profile."

10 (Zum Bericht des Genossen Kostanjan auf dem Fraktionsbüro der Profintern.) Konkrete Vorschläge zur Reorganisierung des Apparates der Profintern, dated 26.7.1933, Appendix to Protokoll (A) Nr. 334 der Sitzung der Politkommission des Pol.Sekr. des EKKI, 15.9.1933, 495/4/261, 143-157, RGASPI.

11 Einberufung einer internationalen Konferenz der ITF-angeschlossenen oppositionellen Verbände, 31.12.1933, 534/5/236, 207-212, RGASPI. 
Shelley returned to Copenhagen and started to implement the RILUinstructions. An order disseminated via the ISH Bulletin instructed the national sections to stop their attacks on the ITF. Focus was instead on the formation of a broad front within the ITF-unions aiming to develop the revolutionary trade union oppositions into national mass movements. ${ }^{12}$

The implementation of the RILU-instructions required a reorganisation of work at the ISH headquarters in Copenhagen. Richard Jensen was made head of the Initiative Committee, established as a legal and public unit in Copenhagen. Due to increased surveillance of the Danish police, all illegally operating units and bureaus of the RILU in Copenhagen were dismantled and transferred to safer locations. This also affected the composition of the IS H (Illegal) Secretariat. Leo Pechmann moved to France where he joined the staff of the RILU Paris Bureau. The ISH (Illegal) Secretariat, in turn, relocated to Antwerp where it started its operations in late April/early May $1934{ }^{13}$ The ISH (Illegal) Secretariat comprised at this point of only two members, namely Adolf Shelley, who started to use the pseudonym 'George', and Adolf Deter, who continued to use his alias 'André. ${ }^{14}$ Ernst Wollweber, on the other hand, remained in Copenhagen and continued to operate his underground apparatus in Germany from the Danish capital. In public, he figured as ISH Secretary. Official declarations and announcements signed by the ISH Secretariat, therefore, were dated in Copenhagen although being drafted in Antwerp. ${ }^{15}$ Luigi Polano, who was running the ISH Sovbureau in Moscow, was the fourth member of the IsH 'inner bureau'.16

One of the most pressing issues for the Is H leadership to grapple was Albert Walter's strange behaviour in Germany. The international campaign for his

12 "Organisiert die innergewerkschaftliche Massen-Oppositions-Bewegung," InformationsBulletin der I.S.H. Deutsche Ausgabe 4:1 (Januar 1934): 4-6, 495/20/858, RGASPI.

13 The exact date for the start of operations in Antwerp is not known. According to British Intelligence sources, the RILU Copenhagen bureau had moved to Paris by 8.5.1933, see Removal of Intenational Committees to Paris, no date, KV 3/127, TNA. The ISH Illegal Secretariat, in turn, seems to have moved from Copenhagen at the end of April, see Leo, Fiedler, and Georges to "Alexander," 7·5.1933, 534/4/493, 105, RGASPI.

14 On the identification of 'George' ('Georges') as Adolf Shelley, see Appendix II.

15 Minutes 8.6.1934, Ernst Wollweber personal file, KV 2/3054, TNA.

16 Polano sent a note to Jensen that the Russian federation of transport workers had nominated comrades Jusefovich, Kamenev and Nikolajenko as its members to the ISH Executive Committee as well as Jusefovich, Kamenev, Nikolajenko, Polano, Makarov, Xecher and Sharikov as members of the ISH Sovbureau. Henri Maurice (signed) to Richard Jensen, [Moscow] 20.12.1933, 534/5/236, 231, RGASPI. 
release from concentration camp had faded away after the publication of his denial of being tortured by the Nazis. Even more obscure was his refusal to emigrate after his release from prison in January 1934. However, when he witnessed against Richard Krebs in court, his former comrades slowly came to realise that Walter had cut his ties with the communists. ${ }^{17}$ In early August 1934, Shelley informed the RILU headquarters that the "company" - i.e., the IS H (Illegal) Secretariat - had expelled Walter. ${ }^{18}$ An official announcement was never published.

The Walter Affaire was probably also on the agenda when the ISH Executive Committee convened in Antwerp in early June $1934 \cdot{ }^{19}$ However, the main topic of the meeting was the organisation of work at the ISH Illegal Secretariat. Present at the meeting was the "inner circle" of the Is $\mathrm{H}$ : Deter, Jensen, Lambert, Pechmann, Schaap and Shelley. ${ }^{20}$ Wollweber and the Norwegian Leif Foss were prevented to attend - the British police disclosed them travelling with forged passports when they disembarked at Harwich on their way to Antwerp and they had to return to Denmark (see further below). Working conditions in Antwerp were not good, Shelley was totally exhausted and wanted to be relieved from his duties. His request was not accepted. ${ }^{21}$ Besides, the lack of a legal secretariat greatly hampered the activities of the ISH. The Executive Committee therefore proposed to establish a legal secretariat consisting of the French Charles Tillon, to serve as official head, as well as Richard Jensen and Josef Schaap. ${ }^{22}$

17 Report by René, 21.7.1934, 534/4/493, 180, RGASPI; Report by “Berndt”, Zur Angelegenheit Albert Walter, 2.8.1934, 495/205/2917, RGASPI; Zur Angelegenheit Albert Walter, 2.8.1934, 534/5/241, 212-213, RGASPI.

18 Excerpt from Shelley's letter, 14.8.1934, 534/5/241, 207, RGASPI; Report by René, 21.7.1934, 534/4/493, 180, RGASPI.

19 Originally, the meeting of the ISH Executive Committee was planned for 20-21 May but it had to be postponed to the end of the month, see Note from Paris, 7.5.1935, 534/4/493, 105, RGASPI.

20 Minutes, 8.6.1934, Ernst Wollweber personal file, KV 2/3054, TNA.

21 Shelley to "Sehr geehrter Herr," 14.7.1934, 534/5/241, 200-206, RGASPI. Shelley repeated his plea to be released from his duties and called back to Moscow in early August; see George to Komfraktion des Vollzugsbüro, A[ntwerp] 4.8.1934, 534/3/1041, 178, RGASPI. This letter clearly indicates that Shelley also used the alias 'George' as the application included a summary of his - Shelley's - activities at the ISH: "I was originally sent to work for 5 to 6 months, at most to the World Congress of the [ISH] but it turned out to become almost $3 \frac{1 / 2}{2}$ years ... I am neither a seamen nor a docker, and I believe that my job is better done by someone who has a background in the maritime industry."

22 Entwurf. Vorschläge zur Diskussion über die Aufgaben der ISH, 19.8.1934, 534/5/241, 222, RGASPI. 
The proposition for establishing a legal secretariat was sent to Moscow but the RILU Secretariat remained silent for months. Deter and Shelley drafted an updated version for the organisational setup of the ISH and sent it to Moscow in October. The dual structure of a legal and an 'illegal' secretariat was to remain. The projected legal secretariat was to be operated by Jensen, Schaap, Tillon, Wollweber, Jusefovich, the leader of the Russian water transport workers' union, and Roy Hudson, the leader of the MwIU. The Is H Illegal Secretariat, in turn, was to be run by Deter and Shelley. In addition, the new plan envisioned Deter, Hudson, Jensen, Jusefovich, Polano, Schaap, Shelley, Verkeest and Wollweber to constitute the new Executive Committee. ${ }^{23}$

An analysis of Deter's and Shelley's proposal gives a hint about the operational basis of the ISH during the second half of 1934. The geographic outreach of the ISH had retracted and comprised only two geographical regions: Scandinavia and Western Europe (Belgium, France, and the Netherlands). The inclusion of Hudson in the inner circle was mere wishful thinking; the IsH Illegal Secretariat had at this point no direct contacts to North America and was not even informed about the strike on the US West Coast. ${ }^{24}$

Following orders from Moscow, the ISH Secretariat prepared statements calling for the opening of discussions with the ITF, and for the establishment of a united front among the maritime transport workers unions in Denmark and France in late $1934 .{ }^{25}$ In November 1934, a confidential circular letter was sent to the leadership of the national sections, calling them to submit proposals for a united front with the IT F. ${ }^{26}$ In December, the RILU headquarters ordered the ISH Secretariat to write an open letter to the ITF, to call for a world congress of the ISH and last, but not least, to move the ISH Illegal Secretariat to France. ${ }^{27}$

The placement of the ISH headquarters remained a hotly debated issue. Antwerp, noted the RILU Paris Bureau, was not an ideal place due to difficult working conditions for the members of the ISH Illegal Secretariat and should therefore be transferred either to France or the Netherlands. ${ }^{28}$ Deter and

\footnotetext{
23 Adolf [Shelley] and André [Deter] to "Komfraktion des Vollzugsbüro der RGI," 26.10.1934, 534/5/241, 253-266, RGASPI.

24 (Copy) Letter from George [Adolf Shelley] to the RILU Secretariat, filed 7.VII.1934, 534/5/ 241, 171-172, RGASPI. On the US Pacific strike, see Pedersen, The Communist Party on the American Waterfront.

25 Vorschläge zur Diskussion über die Aufgaben der ISH, 19.8.1934, 534/5/241, 220-223, RGASPI.

26 Confidential letter to the leading functionaries of the ISH sections, 8.11.1934, 534/5/241, 271-274, RGASPI.

27 Vorschläge der Kommission über die Arbeit der ISH, 2.12.1934, 534/5/241, 293, RGASPI.

28 Report by René, 22.10.1934, 534/4/493, 261, RGASPI.
} 
Shelley backed the plan and opted for France..$^{29}$ No news, no reaction from Moscow for weeks until the RILU Paris Bureau received a positive answer at the end of December 1934: A legal secretariat was to be established in Rouen and headed by Charles Tillon as official ISH Secretary while the ISH Illegal Secretariat was to relocate to Paris. ${ }^{30}$ However, an immediate transfer of the secretariat was not possible and it took another two/three months before the new units had been established in France and started their operations in February/March $1935 \cdot{ }^{31}$

\subsection{The Copenhagen Movement}

The December 1933 meeting in Moscow paved the way for a volte-face in the approach of the ISH towards the ITF. The new strategic considerations rested on two pillars. The first one emphasised strengthening the opposition within the ITF-affiliated unions, the second one on establishing direct contacts with the ITF itself. The strategy further outlined the establishment of a new unit, the Initiative Committee, which was to solidify the first pillar while the ISH was to directly approach the ITF.

A first attempt for formulating concrete actions was made by the ISH (Illegal) Secretariat in early January 1934. A letter addressed to ITF General Secretary Edo Fimmen, in verbatim following the outlines provided by the Confidential Instructions. Framed as a call for cooperation between the ISH and the ITF, it contained a series of demands, such as joint actions against wage-cuts, extension of the working days, dismissals, and rationalisations. Furthermore, it demanded the introduction of 7-hour day in ports and 8-hour day at sea without reduction of wages, full social insurance at expense of the government and the employers, and full employment relief for every day of unemployment. Last, the draft letter called for establishing joint control (vigilance) and strike committees as well as for organising international strike boycotts. ${ }^{32}$

Fimmen never received the letter. Someone in Moscow (?) must have decided that the Is $\mathrm{H}$ should at this stage stay keep a low profile and stay in the

29 Adolf [Shelley] and André [Deter] to RILU, 26.10.1934, 534/5/241, 253-266, RGASPI.

30 Report by René, 29.12.1934, 534/4/493, 79, RGASPI.

31 Note from the RILU technical unit to the RILU information unit, 20.3.1935, 534/5/242, 96, RGASPI. According to British Intelligence information, the ISH Illegal Secretariat had moved from Antwerp to Paris on 20 February 1935, Removal of International Committees to Paris, no date, KV 3/127, TNA.

32 Entwurf (nicht abgeschickt). An das Sekretariat der ITF zu Händen des Generalsekretärs Edo Fimmen, 19.1.1934, 534/5/241, 325-326, RGASPI; Statement of the I.S.H. in connection to the manifestations of seamen and harbour workers for employment, no date, received in Moscow [filed] 29.2.1934, 534/5/242, 87-92, RGASPI. 
background. Instead, the driving force for the new strategy was to bea 'spontaneous' movement among the opposition groups within the ITF-affiliated unions. Moscow's roadmap focused on the formation of the Initiative Committee. The Initiative Committee, not the IS $\mathrm{H}$, was to send a call to all opposition groups within the ITF-affiliated unions; the second step was to summon representatives of these groups to a meeting and transform of Initiative Committee into an Organisational Committee; the third step was the organisation of an international conference of the opposition groups.

Following the 'Confidential instructions', the Initiative Committee was to be formed not later than January 1934. Officially set up by the Danish Stokers' Union, the 'Initiative Committee for the Calling of an International Opposition Conference of Organisations Affiliated to the ITF' (Initiativkommittén til Indkallelse of international oppositionskonference for Organisationer tilsluttede ITF) published an 'Open Letter' signed by Georg Hegner in several languages. ${ }^{33}$ Then - nothing happened.

Most likely, the silence was a combination of internal and external factors delaying operations at the Copenhagen Interclub, the official headquarters of the Initiative Committee. Internally, the move of the ISH Illegal Secretariat to Antwerp must have slowed down operations although the main disturbing factor was an external one, namely the Danish seamen's strike in April $1934{ }^{34}$ Richard Jensen was its mastermind, effectively being a coup by the RFO to organise a 'wild', i.e., illegal strike. The conflict started on 12 April and the communists and the RFO directed all actions. Jensen emerged as the key strike leader, assisted by Ernst Wollweber in the background. Jensen issued an international call for solidarity actions and boycotts of Danish vessels in the name of the ISH - he presented himself as ISH Secretary - and declared of having the full backing of the ISH. He further announced that the ISH had initiated an international campaign and had send 10,00o Francs in support of the strike. ${ }^{35}$

33 A Finnish version of the call, Avoin kirje kaikkille I.T.F. alaisille järjestöille, is filed in the archives of the Finnish State Police, 2404 L Kansainvälinen kommunistinen toiminta (sekalaisia), EK-VALPO, FNA. A summary of the call was disseminated by the illegal German section as "Die Opposition in der ITF stösst vor!," Rote Wache 4, no. 1 (MarchApril 1934).

34 On the Danish seamen's strike, see further Knud Knudsen, "Arbejderkampe i Danmark under verdenskrisen, 1931-34 - skotøjslockouten 1931 og søfolkenes strejke 1934," Årbog for Arbejderbervagelsens historie 6 (1976): $5^{-84}$.

35 See further Weiss, För kampen internationellt!, 378-379. The financial support by the ISH was claimed to originate from its solidarity fund. Although the existence of the fund is not doubted, there are very few documentary traces about when it was established (probably in 1931), how it generated its assets or when it was used. It is not even clear, where the fund existed and who monitored it (was it transferred from Hamburg to Copenhagen or 
Whether the ISH (Illegal) Secretariat had any part in the Danish strike is unlikely. Documentary sources are patchy, and the ISH office in Antwerp seems to have been rather a post box for Jensen's telegrams than an operative centre. ${ }^{36}$ Also, given that the IS $\mathrm{H}$ at this point had an extremely limited budget (and already in August 1933 had to cut its financial assistance to strikes), it seems farfetched to claim that the ISH had any role in the strike.

The Danish strike was a short but violent affair. The communists managed to engage the harbour workers in the strike and especially the "red" port city of Esbjerg emerged as the main battlefield in the fight between the strikers and the police. A general strike paralysed Esbjerg on 17 April and threatened to spill over to Copenhagen. All in vain, after eight days Jensen unexpectedly terminated the strike. The social democrats and socialists trade union leaders mocked Jensen and blamed him and the RFO for having lost the fight. In their mind, the 'wild' strike demonstrated the hollowness of communist rhetoric before the strike - none of the big promises had been achieved. ${ }^{37}$ Wollweber, on the other hand, claimed in his autobiography that the strike had not been a failure. On the contrary, it followed his new strike tactics: Instead of pushing for an endless strike and losing everything, it was to end as soon as one could achieve at least a partial victory. ${ }^{38}$

The strike and its aftermath in Denmark delayed Hegner - or rather Jensen and Wollweber, who pulled the triggers at this state in Copenhagen - from summoning the Initiative Committee for its first (and only) conference in early June. The minutes of the conference reveal that the earlier confrontation tactics and 'Class-Against-Class'-rhetoric was still alive and articulated, not least that the STF and the ITF had betrayed the working class and accepted a "fascistification" of labour laws and a prohibition of (wild/political) strikes. Rather disappointedly (although objectively not surprising), the ITF had reacted negatively to the Open Letter of the Initiative Committee and instead had instructed its member unions to reject any invitations from the opposition. Nevertheless, the delegates at the conference decided to go ahead with the directives from Moscow. Realising that the original plan for summoning

to Paris?). An indication of it being operated from Paris is the claim that the Vancouver harbour workers had received a check for 1,50o Francs from the ISH in support for their strike, see "B.C. Shipowners Face defeat in Waterfront Strike," The Waterfront Worker 3, no. 37 (September 16, 1935).

36 Intercepted telegram Antwerp to Jones/London: Strike Danish Seamen Commenced Stop Danish Ships and Exportwares, signed Richard Jensen, 12.4.1934, Richard Jensen personal file, KV 2/2158, TNA.

37 See further Weiss, För kampen internationellt!, 379-380.

38 Wollweber, Lebenserinnerungen, Nachlass Ernst Wollweber, NY 4327/10, BArchB. 
an international conference during summer proved unrealistic, the delegates decided to postpone it to November 1934. Furthermore, following Moscow's masterplan, the Initiative Committee transformed itself into an 'Organisation Committee. ${ }^{39}$

Together with the Norwegian Leif Foss, Jensen and Wollweber left Copenhagen after the meeting of the Initiative Committee and headed towards Antwerp as they planned to participate at the gathering of the Is H Executive Committee. However, disembarking at Harwich, the British police arrested Foss and Wollweber for carrying forged passports and deported them to a ship returning to Esbjerg. Wollweber managed to escape the Danish police on his return to Esbjerg but realised that underground work in Copenhagen was impossible and fled to southern Sweden. The RILU headquarters, too, came to the same conclusion, and decided in September 1934 to move him to the Soviet Union and placed him as head of the German Section at the Leningrad Interclub. ${ }^{40}$

Wollweber's departure left the ISH without a secretary and someone had to replace him as the official head of the organisation. Shelley and Deter protested against his transfer to Leningrad. ${ }^{41}$ However, Shelley was perhaps not too sorry about his departure. An internal memorandum by a certain 'Georg', i.e., Shelley, criticised Wollweber for having caused the breakdown of the Einheitsverband in Germany and vehemently demanded his replacement by Deter as secretary of the ISH ${ }^{42}$ Several earlier dispatches had hinted about the frictions between the two leading members in the ISH Secretariat. Both were in a sense outsiders and "apparatchniki" although Wollweber, as militant submarine crewmember, had participated in the 1918 naval mutiny in Kiel whereas Shelley had no background in maritime work. Did Shelley's intervention result in the proposal to nominate Charles Tillon as a member of the legal bureau, i.e., the secretariat of the ISH ? $^{43}$

Moscow did not accept Jensen's proposal for arranging the international conference in November. On the contrary, the RILU headquarters criticised the outline of the Initiative Committee for containing several "political faults."

39 Sitzung des Initiativkomitees am 2. Juni in Kopenhagen, 534/5/241, 164-170, RGASPI.

40 Minutes, 29.8.1934, Ernst Wollweber personal file, KV 2/3054, TNA; Wollweber, Lebenslauf, Moscow 4.3.1945, 495/205/8628, RGASPI.

41 Adolf [Shelley] and André to "Komfraktion des Vollzugsbüro der RGI," 26.10.1934, 534/5/ 241, 260, RGASPI.

42 Dispatch from "Georg" to "Liebe Freunde," no date (stamp: 4.8[?].1934), 534/4/493, 184, RGASPI.

43 Vorschläge zur Diskussion über die Aufgaben der ISH, 19.8.1934, 534/5/241, 223, RGASPI. 
Not least, the activities of the Initiative Committee deviated from the RILU masterplan for a rapprochement with the ITF as the planned conference could result in a total split of the unions instead of strengthening the position of the opposition within the unions. The plans for calling an international conference were therefore scrapped and the campaign for its summoning was called off. Instead, the Organisation Committee was transformed into a 'Fighting Committee' (Kampfkomitee) and ordered to lead the "fight for establishing a united front" within the unions. The ISH Secretariat, in turn, was directed to send an appeal to the ITF, calling for the unity of unions and an amalgamation of the ISH with the ITF. ${ }^{44}$

Meanwhile, the IsH Executive Committee had discussed the idea of launching a campaign for the united front of trade unions at its meeting in Antwerp in June 1934. As part of the campaign, the ISH Secretariat redrafted its manifesto for calling a "militant unity front" of all maritime transport workers' unions as well as its statement on inviting the ITF for joint actions in support for higher wages and improved working conditions. ${ }^{45}$ None of the texts were addressed to the opposition but were intended to be sent directly to ITF General Secretary Edo Fimmen. ${ }^{46}$ The IsH Secretariat sent the draft versions to Moscow for approval - and silence followed. ${ }^{47}$ Luigi Polano, who at this point seems to have been transferred to the Is $\mathrm{H}$ Illegal Secretariat, together with Alfred Deter and Adolf Shelley tried to propagate for the 'united front'-campaign by travelling to Czechoslovakia and Austria (Deter), England and France (Polano) and Denmark (Shelley). ${ }^{48}$ However, as the RILU headquarters had not officially backed their campaign, their efforts achieved almost nothing. Nevertheless, the ISH Secretariat stuck to their plan of launching its campaign and informed the functionaries of the (few remaining) IsH sections to start their preparations for the united front. ${ }^{49}$

44 Beschluss des Sekretariats über das Initiativkomitee und über Einheitstaktik, 17.5.1934, 534/5/241, 328, RGASPI; Brief an das Europäische Sekretariat, 7.8.1934, 534/4/491, 31-35, RGASPI.

45 Deklaration der I.S.H. zur Arbeitsbeschaffungsaktionen der Seeleute und Hafenarbeiter, no date, filed in Moscow 23.12.1934, 534/5/241, 317-323, RGASPI; same text but filed 26.3.1935, 534/5/242, 97-102, RGASPI.

46 Entwurf (nicht abgesendet). An das Sekretariat der ITF zu Händen des Generalsekretärs Edo Fimmen, no date, 534/5/241, 324, RGASPI.

47 Vorschläge zur Diskussion über die Aufgaben der ISH, 19.8.1934, 534/5/241, 220-223; Henri [Polano] to "Gen[osse] Alexander," 3.9.1934, 534/5/241, 234, RGASPI.

48 Henri [Polano] to "Gen[osse] Alexander," 3.9.1934, 534/5/241, 233, 235, RGASPI.

49 Confidential! To the leading functionaries of the IsH-sections only!, 8.11.1934, 534/5/271274, RGASPI. 
Moscow remained silent for more than six months. The only news coming from the RILU headquarters was to urge the RILU bureau in Paris to pave the way for a united front in France and Spain by starting the amalgamation of trade unions including those of the maritime transport workers. In France, the process was to be orchestrated by Charles Tillon who was transferred to the Féderation des ports et docks in July $1934 .{ }^{50}$ Shelley was irritated about the unwieldiness of having to send all drafts to the ISH Sovbureau for approval, and suggested that the IsH Illegal Secretariat was mandated to make its own decisions. ${ }^{51}$ Meanwhile, disappointing news came in from Amsterdam at the end of 1934 - the ITF had turned down three invitations to cooperate with the World Committee against War and Fascism. ${ }^{52}$ The ISH Secretariat decided to change tactics and planned to resuscitate the 'Copenhagen Movement', i.e., the Initiative/Organisation Committee, for launching a broadside 'unity campaign' among the ITF-affiliated unions. ${ }^{53}$

Rumours about what was going on in Moscow finally reached Deter in January 1935. The various draft versions of the declarations and manifestos had been handed over to the ECCI Political Commission for approval. Deter protested: According to ISH statues, the ISH Plenum (i.e., Executive Committee), not the ECCI, was to make the final decision. ${ }^{54}$ Instead of waiting for an answer from Moscow, the IsH Secretariat decided to act on its own and sent a letter to the ITF Secretariat in early February 1935. Written in a conciliatory tone (as if the earlier bashing and accusations of "social fascism", "treachery" and "betrayal" never had occurred), the ITF was urged to form a common - united front against the intentions of the shipowners in Northern Europe to introduce drastic reductions in shipping tonnage. ${ }^{55}$

No response, neither from Moscow nor from Amsterdam.

$50 \quad$ Report by René, 13.7.1934, 534/493, 165, RGASPI; Brief an das Europäische Sekretariat, 7.8.1934, 534/4/491, 34, RGASPI. Charles Joseph Tillon (1897-1993) was a leading member of the CGTU, see further Denis Peschanski, "Tillon, Charles Joseph," Le maitron (2009), https://maitron.fr/spip.php?article2428o, accesed 12.6.2020.

$51 \quad$ Adolf [Shelley] and René to "Lieber Freund," 14.11.1934, 534/5/241, 281-282, RGASPI.

$5^{2}$ Leo [Pechmann], Ulrich [?], René, Rudolf [Deter] and Georges [?] to RILU, 12.12.1934, 534/ 5/241, 300, RGASPI.

53 René, Leo [Pechmann], Georges and André [Deter] to RILU, 12.12.1934, 534/5/241, 299, RGASPI.

54 Georges and André [Deter] to RILU, 21.1.1935, 534/5/242, 4-6, RGASPI.

55 ISH, An das Sekretariat der I.T.F., no date, draft arrived in Moscow [stamped] 19.2.1935, 534/5/242, 31-32, RGASPI. 


\subsection{Comrade Edward's Call to Black Maritime Transport Workers}

The reorganisation of the Comintern and RILU apparatuses in Moscow also affected the objectives and capacities of the ITUCNW. In fall 1933, a process started to amalgamate the Eastern Secretariats of the RILU and the Comintern. This also affected the RILU Negro Bureau which was merged with the Negro Bureau of the Eastern Secretariat and formed the ECCI Negro Bureau in January 1934. Strategic and tactical planning for and surveillance of operations in Sub-Saharan Africa and the Caribbean were transferred from the ITUCNW to the new ECCI Negro Bureau. The ITUCNW, in turn, was to continue its operations, including its cooperation with the IS H. On 5 January 1934, the ECCI nominated Otto Huiswoud as head of the ITUCNW and new editor of The Negro Worker. ${ }^{56}$

Huiswoud arrived in Paris in February 1934. After unfruitful negotiations with George Padmore, eventually resulting in the expulsion of the latter from the Comintern and CPUSA in spring 1934, Huiswoud relocated the office of the ITUCNW to Antwerp where he started his operations in April 1934, using the pseudonym Charles Woodson (in internal communications, he used the alias Edward). ${ }^{57}$ About the same time, the Is $\mathrm{H}$ Illegal Secretariat, too, moved to Antwerp. Was this a pure incidence or part of a new masterplan? Reference to work among black or colonial seamen is missing in the new instructions for the Is H. Anti-discrimination, anti-racism and anti-segregation were still on top of the political agenda of the ISH but its operational basis was limited to the revolutionary oppositions within the unions and the remaining Interclubs.

The secretariats of the ITUCNW and the ISH operated illegally in Antwerp. Both used the Antwerp Interclub as a site for connections and inquiries, their offices being at other locations in the town, and their "official" addresses being the Copenhagen Interclub. Huiswouds planned to reactivate work among black seamen and harbour workers in Belgium, Britain, France and the Netherlands, to strengthen the local harbour workers associations in South Africa (Cape Town, Durban, East London, Port Elisabeth as well as Lüderitz Bay), and to reconnect with the British Guiana Labour Union as well as the trade union movement in Trinidad. ${ }^{58}$ Interestingly, no reference was made to the ISH or the affiliation of the associations, groups and unions with the Is $\mathrm{H}$, perhaps an indication of a strategic reorientation being decided upon in Moscow?

The ITUCNW and the ISH continued to cooperate although neither of the two units were to form an umbrella for black maritime transport workers'

$5^{6}$ Weiss, Framing a Radical African Atlantic, 612-614.

57 Weiss, Framing a Radical African Atlantic, 618.

$5^{8}$ Weiss, Framing a Radical African Atlantic, 619. 
unions. ${ }^{59}$ In fact, affiliation with international organisations was not even mentioned in the call to black maritime transport workers published in The Negro Worker in September 1934. Titled "Organisational Task Among the Water Transport Workers," the call urged black seamen and harbour workers to form unions. ${ }^{60}$ Committees of actions were to be set up in every port with the ultimate goal of transforming them into unions:

With the formation of real live functioning groups, which will take up every grievance of the workers (flogging, bad food, fines, small pay and long hours, etc.), unite the workers to put up an effective resistance to every attack of the bosses and to fight for better conditions, the groups be able to win over the workers for the organization of a strong and militant Union of Seamen and Harbour Workers, which will be the only effective instrument in the hands of the workers, to improve their living conditions. ${ }^{61}$

The text has no author, neither is there any reference to an organisation to be the driving force behind the call other than the ITUCNW. However, a close examination of the text reveals that it must have been drafted by the Is $\mathrm{H}$ Illegal Secretariat. The outline of the call as well as its contents closely - almost in verbatim - followed similar ones earlier published by the ISH:

A first step in the direction of organizing a union should be the establishment of small groups of 5 or 7 on the docks, among the seamen on the ships and among the boatmen. As a beginning and to make the work more effective, two or three of the biggest and most important ships and docks or yards should be selected in order to concentrate activities and gain decisive results. After the establishment of such active and functioning groups, general meetings of all workers should be called to discuss their conditions of work and their grievances and the necessity of organization to better their conditions. [...] COMMITTEES OF ACTION should be elected, whose task will be to agitate among the workers and draw them into the groups. [...] The main function of the ship and dock groups

59 The cooperation between the two units is noted by Polano, see Henry to "Lieber Freund," [Antwerp] 1.6.1934, 534/5/241, 111, RGASPI.

60 "Organizational Tasks Among the Water Transport Workers," The Negro Worker 4, no. 5 (September 1934): 16-18.

61 "Organizational Tasks Among the Water Transport Workers," The Negro Worker 4, no. 5 (September 1934): 18. 
must be the mobilisation of the workers for the struggle to obtain the demands adopted. ${ }^{62}$

The call pushed for cooperation between black and white maritime workers on the waterfront in Europe. Above all, the call advocated the radical parole of the IS H for equal pay for equal work regardless of colour or nationality or sex, the complete equalisation of the colonial and white water transport workers, and the abolition of all discrimination because of colour. ${ }^{63}$

If the call of the ITUCNW had any immediate effects is not known. Perhaps its impact was more indirect as its journal was widely read throughout the Black Atlantic. Huiswoud claimed to have established links with the 'Colonial Seamen's Association' in Britain - was this perhaps Harry O'Connell's group and could it indicate O'Connell's continuation as main black Communist instigator on the black waterfront in Britain? ${ }^{64}$

However, Huiswoud's activities in Antwerp ended abruptly in early September when the Belgian police arrested him and his wife Hermine Huiswoud. The Belgian police was looking for a certain 'Charles Woodson', editor-in-chief of The Negro Worker and author of subversive pamphlets. Huiswoud, who carried his official Dutch passport, officially resided in Belgium as free-lance journalist and correspondent or the Crusader News Agency in New York. The Belgian police was never able to link Woodson with Huiswoud but expelled him and his wife. The Huiswouds moved to Amsterdam from where they tried to run the operations of the ITUCNW. ${ }^{65}$ This arrangement proved ineffective and in early April 1935, Deter and Shelley asked the RILU to consider relocating them to Paris. Huiswoud was isolated in Amsterdam, they argued, and a closer cooperation between the RILU European Secretariat and Huiswoud could be established if his office was in Paris. Most importantly, they stressed that the ISH, the League Against Imperialism and the Colonial Commission of the French Party

62 "Organizational Tasks Among the Water Transport Workers," The Negro Worker 4, no. 5 (September 1934): 18.

63 "Organizational Tasks Among the Water Transport Workers," The Negro Worker 4, no. 5 (September 1934): 18.

64 Weiss, Framing a Radical African Atlantic, 626. Huiswoud refers to groups in Cardiff and London. The group mentioned in the call published in the September 1934-issue of The Negro Worker is not to be confused with an organisation carrying the same name, the 1935established Colonial Seamen's Association. The Indian Surat Alley and the Barbadian Chris Jones (Braithwaite) led the latter organisation. Both activists had in the late 1930s/ early 1930s worked for the SMM. Jones/Braithwaite had resigned from the CPGB in 1933 and linked up with George Padmore. See further Høgsbjerg, Chris Braithwaite. 
would support his ambitions to form cadre groups among black mariners and enhance the formation of trade union organisations among black seamen. ${ }^{66}$

Huiswoud, in turn, was sceptical to the idea of moving to Paris. It would be difficult to find an apartment, he claimed, and the costs of printing The Negro Worker would be much higher in France than in the Netherlands. Deter and Shelley did not consider this a major concern and claimed that they could organise for the printing and global distribution of journal. ${ }^{67}$ However, Moscow was late in responding to their request, in part due to escalation of the Ethiopian crisis (see Section 3 in this chapter). At the end of 1935, the Huiswoud's were instructed to move to Paris where they started operations in January 1936.68

\subsection{Hands off Soviet China!}

While Hitler took power in the West, crisis amounted in the Far East. Although the Japanese attack had come to a standstill in northern China, the situation remained tense as Japan refused to return Manchuria to China. Japan was still portrayed as a militarist and imperialist aggressor in communist propaganda publications but a new danger was amounting in China where Nationalist government forces under Chiang Kai-shek started a full-scale attack upon the communist strongholds - the Jiangxi Soviet or 'Soviet China' (Chinese Soviet Republic, established in November 1931) - in Jiangxi Province. Consequently, the Comintern headquarters in Moscow issued a call to defend Soviet China in October 1933 and Polano urged Wollweber to launch a new 'Hands off China'-campaign. ${ }^{69}$

The call for a new campaign was problematic for the ISH Secretariat due to its restricted capacity to act. Wollweber had hitherto spent an uphill battle in organising, supporting and monitoring the underground units of the Einheitsverband in Germany. Effective counter-measures by the German police, however, curbed his ambitions as it had annihilated most of his cells. ${ }^{70}$ However, after consultation with the comrades at the RILU Copenhagen Bureau, the IsH Secretariat managed to produce a pamphlet in December

66 André [Deter] and Georges [Shelley] to "Komfraktion der RGI," 12.4.1935, 534/5/242, 121, RGASPI.

67 André [Deter] and Georges [Shelley] to "Komfraktion der RGI," 12.4.1935, 534/5/242, 121, RGASPI.

68 Weiss, Framing a Radical African Atlantic, 702.

69 M. Henri [Luigi Polano] to "das Sekretariat der Ish zu den Händen des Gen. Strettey Schmidt, 27.10.1933, 534/5/236, 123, RGASPI.

70 Report on activities, "IV. Deutschland," no date [stamp: 16.12.1933], 534/5/236, 230, RGASPI. The author of the report was most likely Wollweber as it contained a briefing on the situation in Germany. 
$1933,{ }^{71}$ calling the national sections of the ISH for the reactivation of the antiwar committees and the blockade of ships with war equipment for Japan and nationalist China, see Figure $36 .^{72}$ By the end of year, the campaign was in full swing. In Sweden, for example, flyers in Danish, i.e., prepared by Danish comrades at the ISH Secretariat, ciculated in the port of Gothenburg while the Swedish RFO-journal Hamnarbetaren urged its readers to back the struggle of the Chinese proletariat and to stop the transport of war equipment to the 'Chinese imperialists', i.e., Chiang Kai-shek and the nationalist Guomindang government. ${ }^{73}$ Similarly, the (illegal) Finnish mimeographed journal Kipinä, hailed the successful actions of the stevedores in Le Havre in November 1933 as an example to inspire the radical harbour workers in Finland to conduct similar expressions of international proletarian solidarity. ${ }^{74}$

The conflict in China intensified in 1934, the communists had to abandon their strongholds in Jiangxi in October and started to retreat to Shaanxi Province (the 'Long March') where they established a new basis for their operations. The RILU European Secretariat in Paris tried at this point to reactivate and coordiante its anti-war activities. It set up a 'planning committee' consiting of the ISH Sectretatiat - which at this point had moved to Antwerp - as well as representatives of the International Propaganda Committees of railway workers and metal workers. ${ }^{75}$ The task of the ISH Secretariat was to open up connections with the ITF and to invite them in unified anti-war activities. ${ }^{76}$ The national sections of the ISH, especially those in Scandinavia, were urged to intensify their anti-war campaigns, notably to stop the transportation of war material to the Far East. ${ }^{77}$ Focus was on Sweden as Gothenburg was the largest export harbour of war material in Scandinavia. As soon as the ISH and the

71 Report on activities, "III. Kampagne zur Verteidigung Sowjetchinas," no date [stamp: 16.12.1933], 534/5/236, 230, RGASPI.

72 [ISH pamphlet] Forsvar Sovjet-Kina - stop al Transport af Krigsmaterial (december 1933), SÄPo Äldre Aktsystemet Volym 118 III B3 s 101 111D: 99, SNA.

73 ISH flyer, dated December 1933, F X:6 Kommunistiska handlingar 1930-1933, Stockholmspolisens kriminalavdelning Rotel 6 med föregångare, SÄPO, SNA; "Sovjet-Kina," Hamnarbetaren. Organ för hamnarbetarna 1, no. 1 (1934): 3-4, SÄPo Äldre Aktsystemet Volym 295 VIII C 3 Interklubb och Röd Marin, Pärm 3, SNA; "Soviet-Kina," Hamn- och sjöproletären 4, no. 5 (1933): 13-15.

74 "Satamatyöläset Le Havressa antavat loistavan esimerkin kietäytymällä sotatarvikkeiden lastauksessa," Kipinä [Winter 1933/4], säPo Äldre Aktsystemet Volym 295 VIII C 3 Interklubb och Röd Marin, Pärm 3, SNA.

75 René, Bericht 24.4.1934, 534/4/493, 224-225, RGASPI.

76 Confidential instructions to the leading functionaries of the IsH sections, 8.11.1934, 534/5/ 241, 271-274, RGASPI.

"Masstransport av krigsmaterial," Hamn- och sjöproletären 4, no. 2 (1934):15-16. 


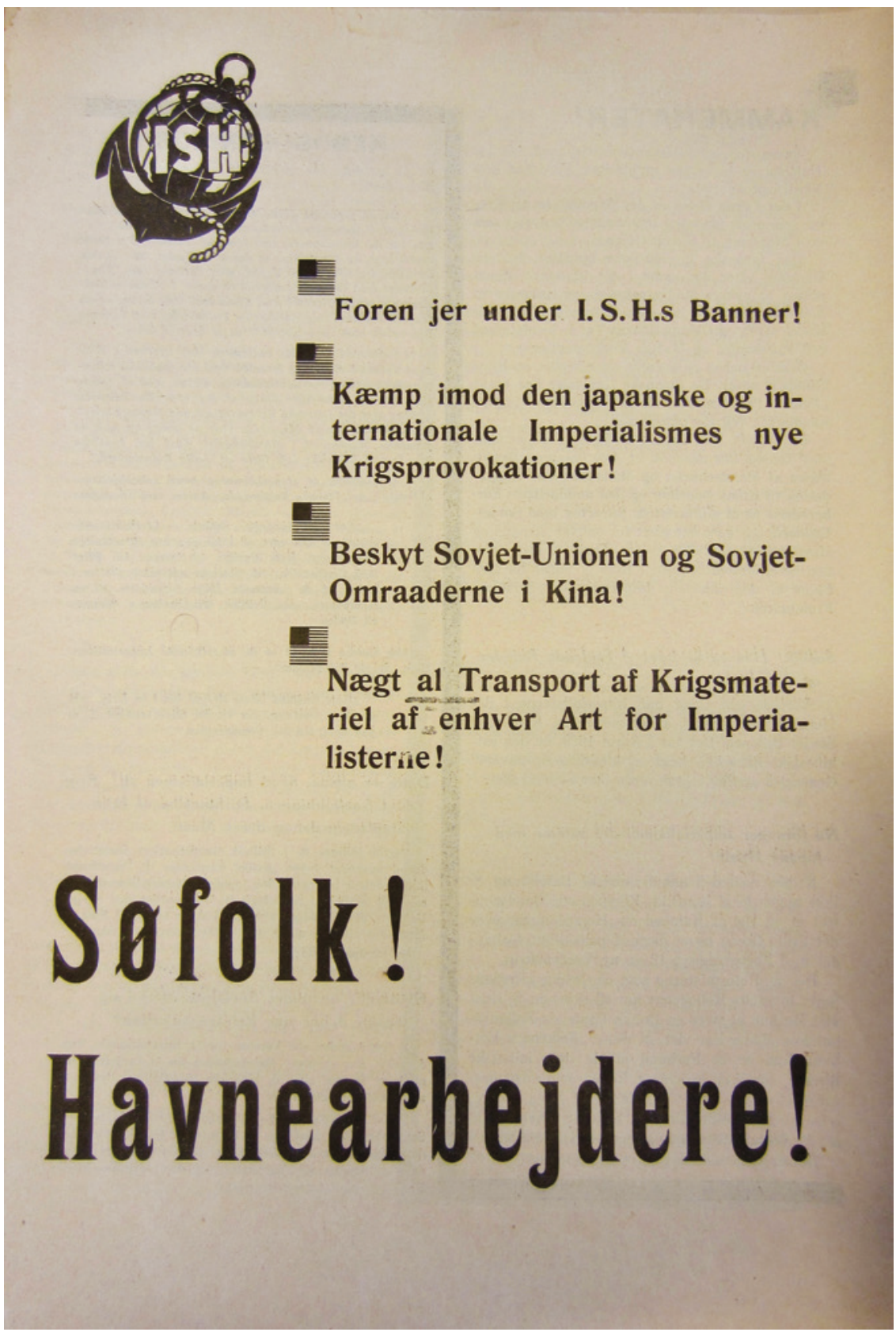

FIGURE 36 Hands off Soviet China! The Danish version of the ISH call of December 1933, inciting the mariners and harbour workers to fight against Japanese imperialism, to defend Soviet China and the Soviet Union, as well as to block the transport of war material to any of the imperialists. Flyer filed in 107 Richard Jensen Arkiv, Danish Labour Movement Library and Archives, Copenhagen. 
ITF had joined hands, local joint 'anti-war committees' were to be established that effetively could monitor and block any transport of military equipment. ${ }^{78}$ Communist anti-fascist rhetoric and anti-war activities had at this point merged, and the IsH leadership declared in June 1934 that the slogan of the forthcoming demonstration on August First was "Against the Imperialist War and Against Fascism."79

All in vain: The ITF rejected the invitation of the ISH. This came as no surprise for the ISH leadership; in fact, now they could once again claim that the 'reformists' had blocked and spoiled unified anti-war activities. ${ }^{80}$

News about a crisis in Stockholm reached the ISH Illegal Secretariat while it was establishing its new headquarters in Paris in early February 1935. Its capacities were already limited as the RILU Paris Bureau declined to strengthen the IsH Illegal Secretariat with additional functionaries. ${ }^{81}$ Then bad news reached Paris.

Decisions concerning work in England and Sweden made at the RILU and Comintern headquarters during winter and spring 1935 were to have far-reaching consequences for the operational basis of the ISH. In February, Moscow dismissed Deter's and Shelley's outline for future work in England. ${ }^{82}$ Worse was to come.

The Swedish section of the ISH, the Sjötransportarbetarnas RFo, had run out of steam in 1934. The Swedish Trade Union Council (Löntagarorganisationen) and the Swedish Seamen's Union had enacted drastic measures after the 1933 strike and expelled 130 leading members of the opposition from the union. The $\mathrm{RFO}$ launched a vigorous campaign against the union leadership but without achieving much success. ${ }^{83}$ Moreover, it tried to counteract further expulsion of opposition members by instructing its remaining union members to sign an

78 "Krigsmolnen tätnar," Hamn- och sjöproletären 4, no. 11 (1934): 1.

79 Appel fra I.S.H.'s Eksekutivkomite - Lad 1. August blive en kampdag imod den imperialistiske Krig og den blodige Fascisme!, ABA.

8o René, Bericht 10.12.1934, 534/4/493, 273-274, RGASPI.

81 René to RILU, 19.2.1935, 534/4/508, 42, RGASPI.

82 Vertraulich. Zu den Richtlinien der Isн über die Arbeit unter den Seeleuten Englands, 11.2.1935, 534/3/1041, 165-166, RGASPI.

83 “Fortsätt aktionen! Mot den bruna mordpesten!," Storm: Organ för Sjötransportarbetarnas RFO 1 (1934); Bertel Lundvik, Solidaritet och partitaktik. Den svenska arbetarrörelsen och spanska inbördeskriget 1936-39 (Uppsala: Acta Universitatis Upsaliensis, 1980), 12-13. 
official declaration stating that they were not members of the RFO. The strategy was a subversive one - the remaining members were ordered to keep a low profile until the forthcoming union congress. However, the plans backfired and the RFO was in disarray. Shelley went to Stockholm in August 1934 to discuss a change in tactics with party leader Sven Linderot. The outcome was a plan to disguise the opposition by abolishing the member cards of the RFO. ${ }^{84}$

The RFO was to remain as a revolutionary trade union opposition, reasoned Shelley. ${ }^{85}$ However, he was not aware that the Central Committee of the SKP had a total different plan. In February 1935, it sent an official request to the ECCI Scandinavian Ländersekretariat to liquidate the Sjötransportarbetarnas RFO. A copy of the letter was sent to the ISH headquarters. ${ }^{86}$ Shelley was furious, sent a telegram to Moscow protesting about the Swedish request, and criticised the Swedish Party for misinterpreting the directives of the ISH. The masterplan, he underlined, was not a liquidation of the RFo but its disguise. ${ }^{87}$ Deter, too, was perplexed and reminded the Swedish Party of the guiding principles of the original masterplan, i.e., the abolishment of member cards and all visible signs of the RFO, and urged the SKP to cancel its plans for organising a conference to liquidate the RFO. ${ }^{88}$ Furthermore, Deter and Shelley notified the RILU headquarters, which, in turn, drafted a similar letter of protest. ${ }^{89}$

The SKP leadership ignored the protest, organised the conference and, without making any public announcement, dissolved the Sjötransportsarbetarnas RFO. ${ }^{90}$ The RILU headquarters, in turn, dismissed Deter's and Shelley's

84 Ad[olf Shelley] and Henry [Polano?] to "Lieber Freund André [Deter]," 23.8.1934, 534/5/ 241, 230-231, RGASPI.

85 Shelley to "Sekretariat des ZK der KPsch zu Händen des Gen. Linderoth," 24.1.1935, Handlingar rörande fackliga frågor, Mapp med diverse handlingar 12, $\mathrm{R} / 7 / \mathrm{F} / 3$, Sveriges Kommunistiska Parti/Vänsterpartiet, ARAB.

86 [Fritjof[L[ager], Till skandinaviska Ländersekretariatet, Komintern, 26.2.1935, 495/15/204, 58-59, RGASPI. The handwritten draft versions of the letter are filed in Handlingar rörande fackliga frågor, Mapp med diverse handlingar 12, R/7/F/3, Sveriges Kommunistiska Parti/ Vänsterpartiet, ARAB.

87 Telegram by Adolphe [Adolf Shelley] to Dengel, sent from Paris 11.2.1935, received in Moscow 20.2.1935, 495/15/204, 6o, RGASPI.

88 Komfraktion der ISH, sign. André [Deter] to zK Schweden, 2.2.1935, Handlingar rörande fackliga frågor, Mapp med diverse handlingar 12, R/7/F/3, Sveriges Kommunistiska Parti/ Vänsterpartiet, ARAB.

89 Georges [Adolf Shelley] and André [Deter] to RILU, 19.2.1935, 534/5/242, 47-48, RGASPI; Entwurf. Über die Reorganisierung der RGO der Seeleute und Hafenarbeiter in Schweden, 15.3.1935, 534/5/1041, 252-253, RGASPI.

$90 \quad \mathrm{NN}$ to ISH, Stockholm, 4.3.1935, Handlingar rörande fackliga frågor, Mapp med diverse handlingar 12, R/7/F/3, Sveriges Kommunistiska Parti/Vänsterpartiet, ARAB. 
protests and accepted the decision of the SKP in early April..$^{91}$ The ISH section in Sweden had ceased to exist.

The final decision on the Swedish question still pending, the RILU Secretariat finally broke the ice and informed the Is $\mathrm{H}$ headquarters about decisions concerning the 'Copenhagen Movement'. Moscow's answer was puzzling. Not a single comment on the drafts of the manifestos and declarations the ISH (Illegal) Secretariat sent to Moscow. Instead, the ISH was ordered to build up a campaign in congruence with the letter sent by the RILU to the Amsterdam International. Not a word about a separate campaign, only a directive to make an official statement in the name of the ISH Executive Committee to support the call of the RILU for the formation of a united front with the Amsterdam International. ${ }^{92}$

About the same time, the ISH Sovbureau decided to publish the IS $\mathrm{H}$ manifesto on full employment. ${ }^{93}$ However, the brochure was never printed. Deter complained that the various corrections to the original version of the text made it unreadable; it therefore had to be rewritten by the IS $\mathrm{H}$ and RILU bureaus in Paris before it could be approved by the ISH Executive Committee which was to meet in May $1935 .{ }^{94}$ Matters were further complicated as the ISH Sovbureau had decided to transform the Copenhagen Movement from an "opposition movement" into a "unity movement" and instructed it to call for an "international unity conference."95 These plans, however, collided with the ambition of the ISH (Illegal) Secretariat to arrange a world congress by itself; the ISH Executive Committee had adopted the plan already in June 1934 but it had never received any approval by the RILU Secretariat. ${ }^{96}$

Nevertheless, Deter and Shelley clung to the idea of calling for a world congress and reformulated the plan in March 1935 by adding an invitation to 'reformist' and anarcho-syndicalist maritime transport workers' unions as well as the ITF. ${ }^{97}$ Moreover, Shelley and Deter proposed that Polano was to

\footnotetext{
91 RGI [RILU] Fraktionsbüro, Protokoll 79, 4.3.1935, 534/3/971, RGASPI; RGI [RILU] Fraktionsbüro, Protokoll 83, 26.4.1935, 534/3/1041, RGASPI.

92 [RILU] to ISH Secretariat, no date, filed 7.4.1935, 534/5/242, 114-116, RGASPI.

93 Protokoll der geschlossenen Sitzung des Sowbüros der ISH vom 9. April 1935, 534/5/242, 133-134, RGASPI.

94 Georges and André [Deter] to RILU, 24.4.1935, 534/5/242, 120, RGASPI.

95 Protokoll der geschlossenen Sitzung des Sowbüros der ISH vom 9. April 1935, 534/5/242, 133, RGASPI.

96 Henri [Polano] to "Gen[osse] Alexander," 3.9.1934, 534/5/241, 234, RGASPI.

97 Georges and André [Deter], Paris 21.1.1935, 534/5/242, 4-5, RGASPI; Georges to RILU, 26.3.1935, 534/5/242, 95, RGASPI.
} 
tour the Latin American countries to agitate for the projected 'unity congress', ${ }^{\prime 8}$ while Shelley was to participate at the forthcoming Seventh World Congress of the Comintern. ${ }^{99}$ The ISH Sovbureau, however, rejected their proposal in April 1935, and demanded the projected Is H world congress to be part of the RILU campaign for a united front with the Amsterdam International. ${ }^{100}$ The RILU Secretariat approved the decision of the ISH Sovbureau, including the plan to summon the ISH Executive Committee for a meeting in Paris. However, the RILU Secretariat rejected the idea of sending Polano to Latin America. ${ }^{101}$

The ISH Executive Committee discussed the transformation of the Copenhagen Movement and the plan to organise a new world congress at its meeting in Paris in June 1935. Organised by the ISH (Legal) Secretariat, which finally had started its operations in early May $1935,{ }^{102}$ the meeting turned out to be the last mustering of the Is H leadership. Whether it reflected the composition of affiliated organisations is questionable as most of its former national sections had ceased to exist, such as those in the USA, in England and in Sweden, or were defunct, such as the RFO in Norway. Nevertheless, 25 delegates turned up at the meeting, including Deter, Polano and Shelley from the Illegal Secretariat. The list of participants indicate the geographical extension of the legal and illegal 'revolutionary waterfront' in 1935: Barneto (Spain), Erikson (Norway), Jensen (Denmark), Hudson (USA), Lambert (Latvia), Robson (England), Rydstedt (Sweden), Schaap (Netherlands), Silverino (Italy), Tillon and Le Winter (France; the former acted as head of the legal secretariat and ISH Secretary in public), and Verkeest (Belgium). Wollweber and Jusefovich did not participate; neither were there any delegates representing the colonial or black maritime transport workers. ${ }^{103}$ The IsH had shrunk into a platform representing the white waterfront only, the global network of Interclub barely existed anymore; see Table 16.

The Is H Executive Committee did not back the idea to transform the Copenhagen Movement into a platform of the opposition within the ITF.

98 Extract of correspondence, signed by Georg [Adolf Shelley] and André, 534/3/1042, 207, RGASPI.

99 Note by André and Henry [Polano], no date [stamp: 20.6.1935], 534/3/1042, 221, RGASPI.

100 Protokoll der geschlossenen Sitzung des Sowbüros der ISH vom 9. April 1935, 534/5/242, 132, RGASPI.

101 Bericht und Vorschläge des Sowbüros der ISH an die Fraktion, no date (stamp: attachment to protocol No. 82, para 6 and 7, 15.IV.1935), 534/3/1041, 348-349, RGASPI.

102 Report by René, $22.4 .1935,534 / 4 / 508,65-68$, RGASPI.

103 Henry to RILU, 15.6.1935, 15.6.1935, 534/5/242, 188-194, RGASPI. 


\begin{tabular}{|c|c|c|}
\hline Country & Port & Address \\
\hline Belgium & Antwerp & Huis der Zeelieden, Brouwerstraat 29 \\
\hline \multirow{2}{*}{ Denmark } & Copenhagen & Gothersgade 15 \\
\hline & Esbjerg & Smedegade 18 \\
\hline \multirow[t]{4}{*}{ France } & Bordeaux & Quai de Chartrond 126 \\
\hline & Dunkirk & Rue de l'Ecluse des Bergues 9 \\
\hline & Marseille & Place de l’Observance 2 \\
\hline & Rouen & Rue Fontanelle 10, Vauxbaillon \\
\hline \multirow[t]{2}{*}{ Netherlands } & Amsterdam & Y.S. Schilp, Raamgracht huis 37 \\
\hline & Rotterdam & Willemskade 7 a \\
\hline \multirow[t]{4}{*}{ Norway } & Bergen & Halfdan Kjerulfsgaten 82 \\
\hline & Haugesund & Store Strandgaten 3 \\
\hline & Oslo & Rödfyldsgaten 12, 2 \\
\hline & Tromsö & Vestergaten 22 \\
\hline \multirow[t]{3}{*}{ United Kingdom } & Hull & Posterngate 24 \\
\hline & Liverpool & 19-20 Old Haymarket Room 12 \\
\hline & North Shields & 24 Elmwood Road \\
\hline \multirow[t]{2}{*}{ Sweden } & Gothenburg & Café Werdandi, Husargatan 19 \\
\hline & Stockholm & Brunnsgränd 4 \\
\hline Uruguay & Montevideo & Muelle Viejo 1640 \\
\hline
\end{tabular}

SOURCE: HAMN-OCH SJÖPROLETÄREN 5, NO. 6 (1935)

Instead, it envisioned the Is $\mathrm{H}$ campaigns for full employment and for a united front to be directed towards groups and organisations who were neither affiliated to the ISH nor the ITF; this, it reasoned, would provide the basis for a larger opposition within the ITF as well as an amalgamation of the ISH with the ITF. On the other hand, the Is $\mathrm{H}$ Executive Committee buried all plans for organising a new world congress. Instead, it adopted the idea to call for a world congress of all maritime transport workers' unions ...104

104 André [Deter], Adolf [Shelley], and Henri [Polano] to RILU, 3.7.1935, 534/5/243, 15-16, RGASPI. 


\section{Calling in Vain for International Solidarity: Hands off Abyssinia}

The Ethiopian crisis started as an incidence involving Italian and Ethiopian troops at the Ethiopian border town of Walwal in December 1934 and escalated to an international crisis during spring 1935. In contrast to the Manchurian crisis, the Comintern remained passive during the Ethiopian Crisis and restrained for months to comment on the issue at all. The silence in Moscow was mainly due to the complicated diplomatic conditions that prevailed in late 1934 and during 1935. Least of all, the Kremlin and the Soviet Foreign Ministry was interested in a high-profile campaign orchestrated by the Comintern. ${ }^{105}$ Officially, therefore, the Comintern restrained from commenting about the Ethiopian crisis until September 1935 (see below). On the other hand, the Political Commission of the Comintern had established a special committee to organise an international campaign against the Italian aggression already in January $1935{ }^{106}$ One month later, the ECCI discussed the crisis. At this point, the ECCI's main interest was to connect the Ethiopian crisis with Japanese imperialism, as it was believed that Japan was trying to establish close military, economic and political relationships with the Ethiopian Emperor. ${ }^{107}$

The first guidelines of the ECCI for political agitation outlined a popular campaign that was to highlight the defence of the national integrity of Ethiopia though not to support the Ethiopian Emperor's regime. The campaign in mind was never projected as a defence of the political independence of bourgeois and imperialist Empire of Abyssinia as such. ${ }^{108} \mathrm{~A}$ few days later, telegrams were sent to the communist parties. The CPGB, for example, was instructed to strengthen its effort to mobilise against the danger of an imperialist war and to expose British imperialism as furthering the Italian aggression. The party was ordered to characterise the Italian aggression as a

105 Haslam, The Soviet Union and the Struggle for Collective Security in Europe, 1933-39 (New York: St. Martin's Press, 1984), 6o-63; Keith Neilson, Britain, Soviet Russia and the Collapse of the Versailles Order, 1919-1939 (Cambridge: Cambridge University Press, 2004); J. Calvitt Clarke III, Alliance of the Colored People: Ethiopia and Japan before World War II (Woodbridge, Suffolk \& Rochester, NJ: James Currey, 2011), 106-107, 124; J. Calvitt Clarke III, "Soviet Appeasement, Collective Security and the Italo-Ethiopian War of 1935 and 1936," in Collision of Empires. Italy's Invasion of Ethiopia and its International Impact, ed. G. Bruce Strang (London and New York: Routledge, 2017 [2013]), 261-286.

106 Ercoli [Palmiro Togliatti] to Lozovsky, 20.1.1935, 534/3/1041, 125, RGASPI.

107 Die japanischen Imperialisten in Abessinien, no author, report dated 22.2.1935, 495/4/459, 1-4, RGASPI.

108 Leitsätze für den Kampf gegen den Krieg in Abessinien, no author, memorandum dated 27.2.1935, 495/11/2, 4-9, RGASPI. 
"colonial predatory war". The Ethiopian side was to be presented as fighting a "war of national independence" despite of its connections with Japan as well as the fact that the country was ruled by "Monarchist feudalist group." Moreover, the party was sanctioned to expose the shipment of war armament through the Suez Canal as a rupture of British neutrality and to popularise the anti-war struggle and 'Hands off Abyssinia'-campaign. ${ }^{109}$ The League Against Imperialism, who had been among the first to react on the Italian aggression in December 1934, ${ }^{110}$ received instructions to get in touch with the World Committee Against War and Fascism in Paris in order to form a delegation for Ethiopia. ${ }^{111}$ One month later, in March 1935, the analysis and guidelines were updated by the ECCI ${ }^{112}$ and a reminder on the campaign was sent to the British, French, Swiss, Spanish and US American parties in April $1935 .{ }^{113}$

The translocation of the ISH (Illegal) Secretariat from Antwerp to Paris in early 1935 hampered its immediate capacity to react to the Ethiopian crisis. The ISH (Illegal) Secretariat, too, had received orders from the Comintern headquarters to link up with the World Committee Against War and Fascism and to receive instructions for the coordination of the 'Hands off Abyssinia'campaign. Anticipating these instructions, the IsH (Illegal) Secretariat issued a call for a 'united front' against Italian fascism and imperialism in March $1935 .{ }^{114}$ Like the previous 'Hands off China'-campaign, the IsH call was not an inclusive one as it stressed the need to defend the "Abyssinian people" and not "Abyssinia", i.e., the Emperor and the prevailing political system. ${ }^{115}$ However, no such instructions were forthcoming which negatively affected the planning of the activities of the ISH. ${ }^{116}$ Consequently, local anti-war agitation in

109 (Intercepted) Telegram Nos. 116-118 from P.C. to C.C., 3 March 1935, published in Nigel West, MASK: MI5's Penetration of the Communist Party of Great Britain (London and New York: Routledge), 147.

110 Annual Report of the League Against Imperialism 1934, 542/1/61, 15, RGASPI.

111 (Intercepted) Telegram No. 115 to Anti-Imperialist League, 3 March 1935, published in West, MASK, 147 .

112 Ferdi: Ethiopie, sous la menance d'invasion imperialiste. Le fascisme italien se lance à une guerre de rapide en Afrique Orientale, 20.3.1935, 495/11/2, 10-27, RGASPI.

113 Peter [Kerrigan] to Harry Pollitt, [Moscow] no date, handwritten add: $3 /$ vi/35, RGASPI 495/20/44, fol. 46. Similar circular letter in German in 495/20/6o9, 10-12, RGASPI.

114 L'I.M.D. pour l'unité d'action dans la lute contre guerre, La Correspondence Internationale 30-31 (13.IV.1935), 495/20/858, 491-493, RGASPI.

115 ISH: Ein neuer Krieg steht unmittelbar bevor - Kriegsmobilisierung Italiens gegen Abessinien (no date but likely written in February/March 1935), 534/5/242, 59-6o, RGASPI.

116 Adolf [Shelley] to "Herrn Alexander [Lozovsky]," 3.4.1935, 534/5/242, 109, RGASPI. 
the harbours and on board the ships was not organised and the 'Hands off Abyssinia'-campaign never took off in spring $1935 .{ }^{117}$

Responding to the inactivity in Europe, a special commission of the Comintern urged the World Committee and IsH to cooperate closely and ordered the IsH to prepare two brochures, one about the seamen and the war, another about the harbour workers and the war. Officially, the publications were to be published in the name of the World Committee as to shield off the ISH against any attacks by the government authorities. In addition, the World Committee and the ISH were to concentrate their anti-war agitation to a few ports as to achieve concrete results by the action and vigilance committees in their efforts to block and boycott the transportation of war material to East Africa. ${ }^{118}$ Moscow's instructions reached Paris in June and comrade René at the RILU bureau discussed them with representatives of the ISH (Illegal) Secretariat and the World Committee in conjunction with the meeting of the ISH Executive Committee in early May 1935. The meeting decided to start a joint campaign although its outcome depended on the active participation of and support by the communist parties. Therefore, René urged the RILU headquarters to remind the parties of the decisions made at the XIII Plenum of the ECCI with regards to work among seamen, as their implementation had been slow in materialising into concrete action. ${ }^{119}$

The first official comments of the Comintern on the Ethiopian Crisis were made by Palmiro Togliatti, who presented a report on 'the preparation of a new world war by the imperialists and the tasks of the Communist International' at the Seventh World Congress of the Comintern on 10-11 August 1935. According to him, Japanese imperialism and German fascism were the main advocates of war. Togliatti also attacked Italian imperialism, shortly touched upon the threat of an Italian invasion of Ethiopia and made a passionate declaration of solidarity with the Ethiopian people. ${ }^{120}$ The resolution on Togliati's report concluded that Mussolini's impending invasion of Ethiopia was creating a new tension in relations between the imperialist Powers - echoing the position of

\footnotetext{
117 Report by Henri [Luigi Polano], André [Adolf Deter] and Ad[olf Shelly] on the activities of the ISH in 1935, January 1936, 534/5/245, 12-13, RGASPI.

118 Sitzung der Kommission zur Beratung der im Brief des Genossen Adolf (ISH) aufgeworfenen Fragen über die Zusammenarbeit mit dem Weltkomitee, 3.5.1935, 495/30/1082, 2, RGASPI. Members of the commission were Vassiliev, (Bela) Kun, Polano, Jusofovich and Heckert.

119 Report by René, 12.6.1935, 534/4/508, 112-115, RGASPI. The report was discussed by the RILU secretariat two weeks later, see 534/3/1042, 191-194, RGASPI.

120 Aldo Agosti, Palmiro Togliatti. A Biography (London and New York: I.B. Tauris, 2008), 100-102.
} 
Soviet foreign policy rather than articulating a clear-cut condemnation of Italy and a call to rally behind the cause of Ethiopia. ${ }^{121}$

In late August, the Comintern issued the "Declaration of Support for Abyssinia" and sent it to the Communist Parties of Brazil, Cuba, France, Great Britain, Italy, Panama, Portugal, South Africa, and the USA. ${ }^{122}$ These were the first official instructions sent by Moscow, opening the way for the application of a 'United front'-policy in the Ethiopian campaign. Still, no public statement had been forthcoming and a representative of the CPGB inquired whether the ECCI is going to prepare one or if the European parties were supposed to issue a joint one?123 Back in Moscow, Palmiro Togliatti's Secretariat was ordered to prepare a report on the Ethiopian crisis after the Seventh Congress. The ECCI Presidium discussed Togliatti's report on 26 September $1935 .{ }^{124}$ A few days earlier, the ECCI Secretariat had published an appeal by Comintern General Secretary Georgi Dimitrov to form a united front with the Labour and Socialist International to prevent the escalation of the conflict into a new world war. ${ }^{125}$ Furthermore, instructions were sent to the CPGB ordering them to establish contacts with the PCF in order to launch a broad public campaign along the popular front-doctrine, i.e., aiming to include the British Labour Party, the Socialist League, and the Independent Labour Party. ${ }^{126}$

The ISH Secretariat started to plan for a new campaign after the Seventh World Congress of the Comintern in August 1935. It launched a call for an international boycott of Italian vessels and shipments of war equipment to Italy in September 1935. The Is H even tried to establish a 'unity front' of transport workers by calling - officially by ISH Secretary Charles Tillon - for a joint campaign with the ITF on 21 September 1935 but failed miserably as the ITF refused to recognise the ISH as an equal partner. ${ }^{127}$ Dimitrov's invitation to the Labour and Socialist International to form a united front against Italian

121 E. H. Carr, The Twilight of the Comintern 1930-1935 (Basingstoke: MacMillan, 1982), 413-416.

122 Declaration of Support for Abyssinia, 28.8.1935, 495/14/6o, 22-25, RGASPI.

123 (Intercepted) Telegram No. 97 from West to Secretariat, 11 September 1935, published in West, MASK, 8o.

124 Agosti, Palmiro Togliatti, 104.

125 Telegram from the ECCI Secretariat to the LSI Secretariat on the Danger of War in Abyssinia, 23.9.1935, in Degras (ed.), The Communist International, 378.

126 (Intercepted) Telegram Nos. 380-383 from Peter and Ercoli [Togliatti], 22 September 1935, published in West, MASK, 165 .

127 Tillon to "Gen[osse] Jusofowitsch," 12.10.35, 534/5/243, 116, 173-177, RGASPI; Report by René, 29.10.1935, 534/4/508, 146, RGASPI About the non-engagement of the ITF in the Abyssinia campaign, see Willy Buschak, Edo Fimmen. Der schöne Traum von Europa und die Globalisierung (Essen: Klartext Verlag, 2002), 188. 
imperialism met a similar fate. His first call received no answer; a second call was sent to London a few days after the Italian attack on Ethiopia in early October. ${ }^{128}$ Similar appeals for a united front against the Italian imperialism were made by the League Against Imperialism and World Committee Against War and Fascism. ${ }^{129}$ All in vain, the Socialist and Labour International was not interested in a unified campaign instigated by the communists.

The Is $\mathrm{H}$ call for an international boycott had a global circulation. However, local boycotts had been initiated well before the circulation of the ISH call. In Trinidad, for example, the Longshore Workers' Branch of the Trinidad Labour Party had started its activities before they were contacted by the ISH Secretariat and were asked to join a worldwide boycott of Italian ships. The union members decided to back the ISH boycott and even issued a declaration of it in the Trinidad Guardian on 25 October $1935 \cdot{ }^{130}$

The IsH Secretariat issued a new call for international unified cooperation when the Italian troops started its attack on Ethiopia in early October 1935. The call, which was published in the magazines of the national sections of the ISH, underlined that the need for a global blockade of war material to the Italian troops. This blockade was to be organised by the transport workers in the harbours and by the ship crews. Still, however, the vocabulary of the text echoed the communist position: Global support was called for the defence of the "Abyssinian people" and its "war of liberation" as well as for the defence of "world peace."131

The October 1935 call of the ISH was in part a response to local actions in Europe and Africa. The crew of five Greek ships protested against shipments of war material for the Italian troops. The harbour workers in Alexandria (Egypt), Cape Town and Durban (South Africa), Bombay (India) and Marseille (France) refused to load Italian ships. None of these activities, it seems, had been coordinated by the ISH Secretariat but by local committees and activists. Instead, the ISH Secretariat used the activities as expressions of international

128 Telegram from the ECCI Secretariat to the LSI Secretariat 7.10.1935, in Degras (ed.), The Communist International, 378.

129 R. Bridgeman, Statement by the League Against Imperialism and for National Independence for the Defence of the Independence and Territorial Integrity of Ethiopia, 8.10.1935, 542/1/62, 62-63, RGASPI.

130 Correspondence between the ISH Secretariat to the Secretary of the Stevedores' and Longshore Workers' Branch of the Trinidad Labour Party, 24.9.1935, reply from Trinidad, 6.11.1935, 534/5/243, 156-16o, RGASPI. See further Featherstone, "Contested spaces of maritime organising," 166.

131 "Rädda freden ... Upprop från IsH till alla världens sjötransportarbetare," Hamn- och sjöproletären 5 , no. 10-11 (1935): 6. 
proletarian solidarity. ${ }^{132}$ Similar strikes and boycotts were organised in the USA (San Pedro), the United Kingdom (Cardiff; London), France (Port Sant-LouisDu-Rhone; Marseille), Belgium (Antwerp), Greece (Piraeus), Egypt (Port Said), Algeria (Bone) and Southwest Africa/Namibia (Lüderitz Bay). Although they were listed in the ISH magazines, these actions, too, had either been organised by local anti-war committees, sections of trade unions or ship crews that had few, if any connections to the Is $H$ Secretariat. ${ }^{133}$

Nevertheless, the ISH Secretariat continued its campaign and issued several calls for a boycott of Italian ships throughout the autumn of 1935. In November, the RILU bureau in Paris reported that ITF Secretary Edo Fimmen and the ISH had started discussions on joint actions. ${ }^{134}$ However, nothing came out of these negotiations. Disappointed about the negative stance of the ITF, the ISH (Illegal) Secretariat published the correspondence on its attempt to establish a united front. ${ }^{135}$ If the Is $\mathrm{H}$ publication had any effects is doubtful, as no joint actions were forthcoming in the ports. ${ }^{136}$ At this point, however, the campaign had developed - as in 1934 - into a general campaign against the impending Imperialist War. In November 1935, the ECCI instructed the RILU and its affiliated organisations, including the ISH and the ITUCNW, to intensify the campaign against Fascist Italy and to broaden it to include actions against Germany and Japan:

The beginning of military operations in Abyssinia increases the danger of war in Europe and especially the danger of a military attack by fascist Germany on Lithuania to conquer the Memel district and launch a war against the Soviet Union; Czechoslovakia and Austria are also in danger of an attack by German fascism. [...] The beginning of the war in East Africa and the unleashing of all imperialist desires in Europe is inevitably

132 List of slogans, 534/5/243, 184, RGASPI. See further Featherstone, "Contested spaces of maritime organizing," 165-168.

133 "Internationellt," Hamn- och sjöproletären 6, no. 1 (1936): 10; "Sjötransportarbetarnas kamp mot det italienska kriget i Abessinien," Hamn- och sjöproletären 6, no. 4 (1936): 3. The actions and boycotts against Italian vessels noted in The Waterfront Worker during late 1935/early 1936, for instance, had no connections to the IsH but had been organised by local groups.

134 Report by René, Gaston and Robert, 12.11.1935, RGASPI 534/4/508, 155, RGASPI.

135 IS H, For the Unity of the Transport Workers in the Struggle Against War - Correspondence between the International of Seamen and Harbour Workers (ISH) and the International Transport Workers' Federation (ITF) regarding Mussolini's attack on Abyssinia, December 1935, 534/5/243, 173-177, RGASPI.

136 Report by Gaston, Robert and René, 3.12.1935, 534/4/508, 159-162, RGASPI. 
bound to lead to a widening of the war of plunder of Japan in China and to new anti-Soviet provocations by Japan."137

In early January 1936, the ISH Secretariat followed suit and published a call for unified action against Italian and Japanese Imperialism. What haunted was the fear of an assault on the Soviet Union: "The Italo-Abyssinia conflict commands our attention today, tomorrow the conflict between Japan and the Soviet Union." The members of the national sections of the IsH were urged to stop the transportation of war materials to the Horn of Africa ... ${ }^{138}$

It is doubtful if the IsH appeal of January 1936 had any impact. Few of its national sections existed anymore at this point and effective actions were limited to a few port cities in Europe. Even the Is H leadership had to admit that their appeal had no effect. ${ }^{139}$ When the Italian troops entered Addis Ababa in May 1936, the ISH had been silent for over 5 months.

Dissolution

The disbandment of the ISH was a direct consequence of the strategic reorientation in Moscow in 1933/34. Although the 'Class-Against-Class'-doctrine had not been revoked in public, the opening for a united front between the communists, socialists and left-wing leaning bourgeois parties in France and Spain, the so-called Popular Front, signalled a re-orientation at the Comintern headquarters. In fact, the plan of amalgamating the RILU with the Amsterdam International was among the first tactical steps outlined in Moscow. The discussions at the XIII Plenum of the ECCI and especially at the Commission for work among seamen in December 1933 set the turn also for future work among maritime transport workers by focusing on the opposition within the ITF-affiliated unions and, as a consequent end goal, to amalgamate the ISH with the ITF. 'Class-Against-Class'-rhetoric was to be silenced as to give room to strengthen the opposition within the ITF-affiliated unions.

Moscow notified the parties about its new tactical considerations through the December 1933 Resolution on work among seamen and harbour workers. The application of the December 1933 Resolution was detrimental to the

137 The Struggle against the Italian attack on Abyssinia and against the activisation of the military aggression of Germany and Japan, 13.11.1935, 495/20/1, 16-19, RGASPI.

138 Einheitsaktion gegen den japanischen Imperialismus, 3.1.1936, 534/5/245, 1-3, RGASPI.

139 Bericht über die Internationalen Seeleuteklubs und einige Vorschläge zu ihrer weiteren Tätigkeit, 31.3.1936, 534/5/245, 107-117, RGASPI. 
global outreach of the ISH. By 1934, it was evident for all that the ISH (Illegal) Secretariat had ceased to be a global player (if it ever had been one). Neither the Copenhagen nor the Antwerp Secretariat had any direct links to revolutionary opposition groups or red unions in the Pacific or Atlantic region; its core units were the few remaining Interclubs in Belgium, France, the Netherlands and Scandinavia. Other Interclubs, such as those in New York and Montevideo, were not directly linked to the Is $\mathrm{H}$ (Illegal) Secretariat, and none of the Interclubs were at any point monitored or directed by it.

The winding up of the IS $\mathrm{H}$ as a global platform for revolutionary trade union opposition units and red unions started with the dissolution of its sections in England and the USA in 1934. The SMM was quietly buried. The MWIU had been involved in the strikes on the US West and East Coast in 1934 but analysing its rather limited impact, the CPUSA favoured its liquidation. Moscow sent an order in December 1934 to dissolve the MWIU: The CPUSA was to focus on working through the opposition in the International Seamen's Union (ISU); the MWIU journal The Marine Worker's Voice was to remain as the mouthpiece of the ISU-opposition. ${ }^{140}$ Similar directives were sent to Sweden a few month later; the RFO was dissolved, its journal Hamn- och sjöproletären was to continue as the mouthpiece of the SKP sjöcell (sea cell) and the communist fraction in the seamen's union. ${ }^{141}$ Karlis Ulmanis' putsch on 15 May 1934 marked the end of the communist-controlled Latvian Seamen's Union. The opposition went underground and was incapable to link up with the ISH Secretariat. ${ }^{142}$ In Danzig and Finland, too, the (illegal) ISH sections ceased to exist by 1934/35. In 1935, negotiations started on amalgamating the FUMP with the other French seamen's unions. ${ }^{143}$ By October 1935, the ISH numbered but one legal national section, the Danish Stokers' Union, and two illegal ones, namely the Greek and Italian seamen's unions. ${ }^{144}$

Moscow's ultimate aim had been to merger the ISH with the ITF. The ISH Secretariat would not be abolished but remain as the mouthpiece of the opposition within the ITF and its affiliated unions. Most importantly, the ISH was to be transformed into a global platform within the ITF embracing all nonaffiliated unions of maritime transport workers in Africa, Asia and Latin

140 Vernon L. Pedersen, "It's Hard to be Popular: The Marine Workers Industrial Union and the Coming of the Popular Front," American Communist History 11, no. 3 (2012): 285-293. See also Pedersen, The Communist Party on the American Waterfront.

141 Weiss, För kampen internationellt!, 395.

142 Bericht von Avotin [Lambert], no date [stamp: 12.4.35], 534/5/241, 147-148, RGASPI.

143 Report by René, Gaston and Robert, 12.11.1935, 534/4/508, 155-157, RGASPI.

144 NN to "Liebe Freunde," 5.10.1935, 534/5/243, 112, RGASPI. 
America. The kick-off for such vaulting visions were regional conferences to be organised all over the world ... ${ }^{145}$

The transformation of the ISH never materialised. The ISH (Illegal) Secretariat attempted to intervene at the congress of the Swedish Seamen's Union in October 1935 but failed miserably. The communist fraction had tried to establish a united front with the socialists in 1935, and the ISH (Illegal) Secretariat believed that the united opposition would constitute the majority at the congress. Shelley, and probably Deter, travelled to Sweden to instruct the communist delegates at the congress. ${ }^{146}$ The united front turned out to be a chimera - the socialists did not support the communists at the congress. Tactics failed: Only six of the pre-elected 57 delegates were communists and the congress rejected all of their motions. ${ }^{147}$ Deter and Shelley sent a critical note to the Swedish Party and criticised it for its lukewarm engagement in pushing for a united front in the seamen's union. ${ }^{148}$

Autumn 1935 was the swan song of the ISH. The ITF turned down the invitations for the establishment of a united front. The outcome of the Swedish congress cut the plans for a Scandinavian secretariat. The ISH (Illegal) Secretariat was in decay - Deter was ordered to work at the illegal secretariat of the German Party in Paris, Shelley complained about being exhausted, and Polano awaited his transfer to Latin America. ${ }^{149}$ By early November, the ISH existed but in name. Work among the maritime transport workers had been transferred to the parties; the revolutionary trade union opposition had ceased to exist. What was left were the Interclubs, and the Is H-troika Deter-PolanoShelley decided to concentrate their efforts on them. ${ }^{150}$

The last chapter of the ISH as a member organisation closed when the Danish Stokers' Union cut its ties in spring 1936. The U-turn of the Comintern and the official implementation of the 'Popular Front'-doctrine after August

145 Memorandum über die Arten der internationalen Arbeit unter den Wassertransportarbeitern, besonders im Zusammenhang mit dem geplanten Welteinheitskongress, und über die Perspektiven der ISH, 1.9.1935, 534/5/243, 83-88, RGASPI; NN to "Liebe Freunde," 5.10.1935, 534/5/243, 112, RGASPI.

146 Ad[olf Shelley], Henri [Polano] \& André [Deter], Report on 'Seeleutegewerkschaft Schweden', 24.10.1935, 534/5/243, 125-126, RGASPI.

147 "Sjöfolket ville icke ha kommunister," Sjömannen 9 (1935): 286; “Om kongressen," Sjömannen 10 (1935): 305-306.

148 "Komfraktion des Sekretariats der ISH" to "Sekretariat der KP. Schwedens," 1.10.1935, 534/ 5/243, 127-128, RGASPI.

149 Adolf [Shelley] to "Sehr geehrter Herr Alexander," 5.10.1935, 534/5/243, 115, RGASPI.

150 Adolf [Shelley], Henri [Polano], André [Deter] to RILU, 6.11.1935, 534/5/243, 149-150, RGASPI. 
1935 also required the Danish ISH-affiliated stokers' union to follow suit. ${ }^{151}$ However, the social democratic-controlled unions in Denmark repelled the invitations of the communists. ${ }^{152}$ The Danish question was discussed at a meeting in Moscow in February 1936. Shelley and Jensen were present, the latter's objection to the amalgamation was overruled. ${ }^{153}$ Deter and Polano as well as the ISH Executive Committee (or what was left of it; probably only the Belgian, French, and Dutch comrades) accepted the secession of the Danish Stokers' Union in March 1936. ${ }^{154}$ The union applied for its re-entrance to the ITF at the conference of the Scandinavian Transport Federation in June 1936. At this point, the IS $\mathrm{H}$ had already ceased to exist.

\subsection{Back to Square One: A Liaison Office for Interclubs}

The last signs of the IsH are hazy. The legal secretariat was located in Rouen but used Tillon's office in Paris as its official post box for its correspondence; see Figure $37 .{ }^{155}$ The illegal secretariat operated from Paris, consisting of Deter, Polano and Shelley as well as three assisting functionaries until early 1936. At least two of the external members, comrades 'Paul' and 'Gertrud', seem to have been members of the RILU Paris Bureau whereas the third member, 'Boris Ginzburger', was a member of the PCF. Shelley received instructions in late December 1935 to travel to Moscow. ${ }^{156}$ Ten days before his departure, an internal control commission consisting of comrades André (Adolf Deter), Henri (Luigi Polano) and 'Barri' (presumably Bari of the RILU bureau in Paris) made an investigation of the accounts of the illegal secretariat. The audit had been prompted by rumours about financial irregularities of the ISH but the investigation cleared Shelley and he was allowed to leave Paris. ${ }^{157}$

151 Sitzung der Exelutive der RGI am 7.2.1936: Unsere Gewerkschaftsarbeit in Dänemark und die spezielle Lage im Seeheizerverband. Referat Genosse Jensen, 534/3/1089, 26-27, RGASPI.

$15^{2}$ NN to "Werte Genossen," 13.8.1935, 534/5/243, 68, RGASPI; NN to "Liebe Freunde," 5.10.1935, 534/5/243, 112, RGASPI.

153 Sitzung der Exelutive der RGI am 7.2.1936: Unsere Gewerkschaftsarbeit in Dänemark und die spezielle Lage im Seeheizerverband, 534/3/1089, 68, RGASPI.

154 André [Deter] and Henri [Polano] to "Komfraktion der RGI," 26.3.1936, 534/5/245, 62, RGASPI; Exekutivkommitee der IS H an Hauptleitung des Seeheizerverbandes Dänemarks, no date, 534/5/245, 140-145, RGASPI. I have not found any agenda for the ISH Executive Committee Meeting in March 1936, presumably held in Paris?

155 As stated on the letterhead of the IsH Bulletin, Service d'Information et de Presse de l'IMD. Some of its issues are filed in 534/5/246, RGASPI.

156 Report by René, 24.12.1935, 534/4/508, 167-171, RGASPI.

157 Boris Ginzburger (signed) to NN, Paris 29.3.1937. This letter is one of the few documents about Shelley's fate. It is a type-written letter added with hand-written insertions of names 


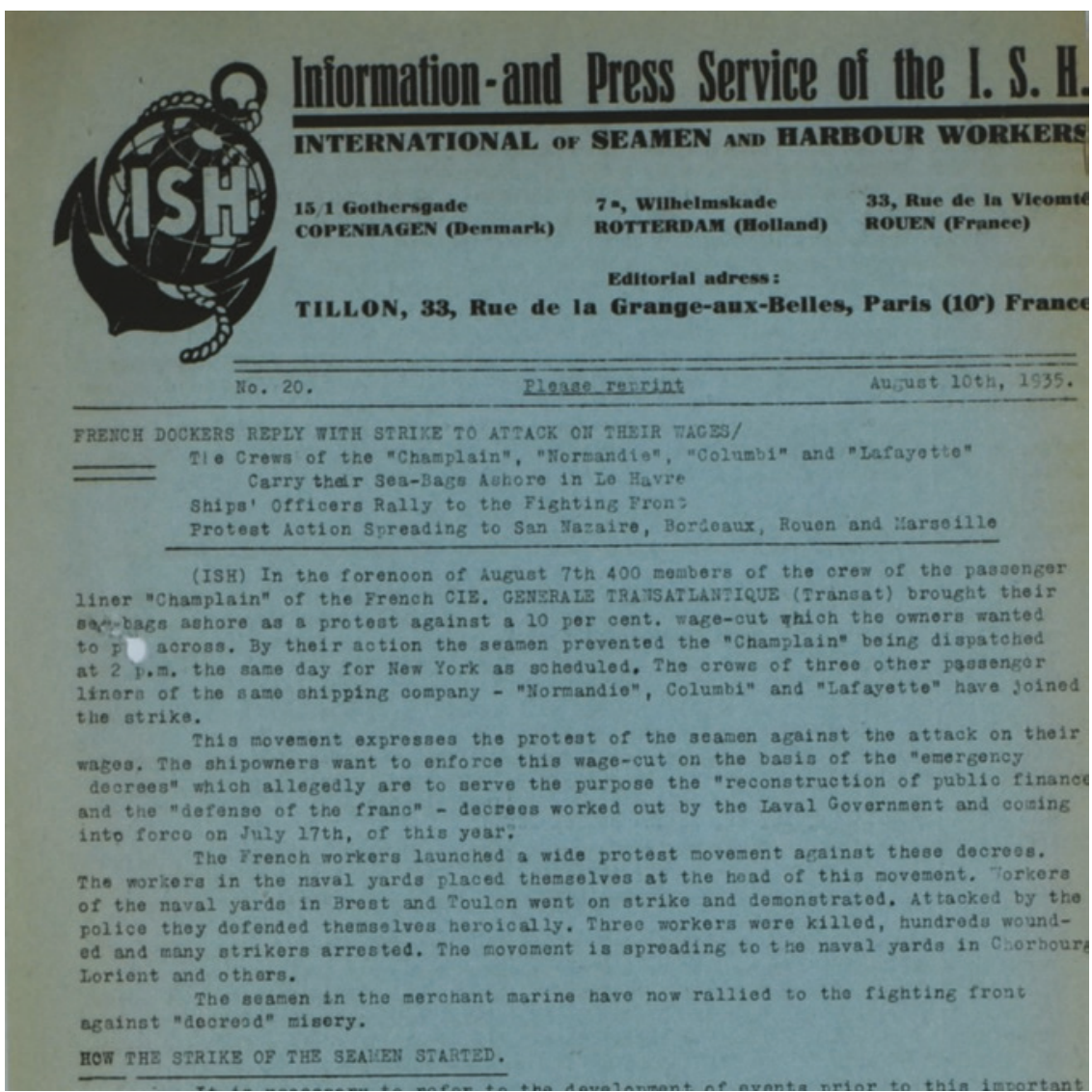

FIGURE 37 Information and Press Service of the ISH, the bulletin published by the ISH Secretariat from Rouen/Paris when the organisation had shrunk into a mere liaison office for Interclubs; No 20 of 10 August 1935, filed in HO 144/20657, TNA.

and organisations as well as the signature 'Boris Ginzburger'. The original letter, most probably in hand-writing, had been addressed to someone at the French Party. A typed copy of the letter was sent by comrade Duclos to Moscow and, for reasons not known, one copy of it (or was it the original dispatch?) is filed in Luigi Polano's personal file, 495/ $221 / 425,81-83$, RGASPI, indicating that it either was used by him in his investigation on the ISH in spring 1937 or was added to his personal file by someone at the International Control Commission as part of an internal assessment of Polano. 'Boris Ginzburger' was perhaps the alias of French communist Roger Walter Ginsburger (1901-1980), who assumed the name Pierre Villon as a member of the French Resistance. Ginzburger is known to have worked as ISH instructor in Antwerp in 1935 and collaborated with ISH Secretary Charles Tillon, see Claude Willard, "Villon, Pierre," (2019) Le Maitron, https:// maitron.fr/spip.php?article134754. 
The approvement of the internal control commission did not clear the air but resulted in the intervention of comrade Paul who claimed the investigation to be faulty and called for the nomination of a new control commission. Deter protested, refuted Paul's insinuations about Shelley having added forged receipts to the IsH accounts, and demanded to wait for Shelley's return to hear his explanation. However, Deter's protests were overruled and a second internal control commission was nominated, consisting of comrades 'Robert', 'Barri' and Henri (Luigi Polano). A thorough investigation followed with disastrous results: The accounts were declared a forgery as several receipts consisted falsifications and irregularities. The commission criticised Deter, who had been in charge of the accounts, for having failed to check Shelley's receipts and use of ISH funds. Deter, in turn, responded that he had trusted Shelley and there never was any suspicion against him. On the other hand, comrade Robert rejected Ginzburger's call for an investigation on the cooperation between the ISH and the PCF. According to him, the task of the commission was to check the accounts of the ISH, not its operations. Ginzburger, however, received a box containing the receipts of the ISH and was ordered to hide them in a safe place. ${ }^{158}$

Shelley never returned to Paris. Documentation about his translocation is lacking although he seems to have been working for the Is H Sovbureau until March 1936 when he disappeared from the stage. ${ }^{159}$ Whether the investigation on the ISH accounts and the accusations of falsifications were used against him is not known. None of his comrades knew what had happened to him, only a German surveillance report from the Second World War revealed that he was one of the millions who succumbed during Stalin's purges and the Great Terror. Accused for having a bourgeois background, for serving as an officer in the Polish army, and for being a Polish spy during the 1920's, he was arrested by the NKVD on 25 July 1937, sentenced to death on 25 December 1937 and shot the same day, most probably in the cellar of the Lubyanka Building in Moscow. $^{160}$

$15^{8}$ Letter by Boris Ginzburger, Paris 29.3.1937, 495/221/425, 82-83, RGASPI.

159 My claim of Shelley placement at the IsH Sovbureau rests on two letters addressed to him. The first one was sent by Deter about the committee of the unemployed in Antwerp being infested by fascists, see André to "Alexander" with handwritten add: "Für Adolf," 9.1.1936, 534/5/245, 10, RGASPI. The second letter contained information about Hermann Knüfken and his activities in Antwerp, see "Für Adolf," no date [stamp: 13.3.1936], 534/5/ 245, 6o-61, RGASPI.

160 "Alfred Brunon Bem,“ https://pl.wikipedia.org/wiki/Alfred_Brunon_Bem; Wladislaw Hedeler, "Möglichkeiten und Grenzen bei der Erstellung von Kollektivbiographien," in Biographisches Handbuch zur Geschichte der Kommunistischen Internationale. Ein deutsch-russisches Forschungsprojekt, eds. Michael Buckmüller und Klaus Meschkat 
The downscaling of the ISH Illegal Secretariat was a consequence of the dissolution of the ISH as the mouthpiece of the red seamen's unions and the revolutionary trade union oppositions within the maritime transport workers' unions. None of them existed anymore by spring 1936; the red seamen's unions and revolutionary trade union oppositions had either been dissolved or had amalgamated with the existing unions. The communist fractions within the unions were part of the national parties, not the ISH. What remained were the Interclubs whose status remained to be defined - were they to constitute the backbone of a transformed IsH or to be transferred to the national unions? The members of the ISH Illegal Secretariat pushed for the first alternative, namely to transform the ISH into the headquarters for the dissemination of propaganda via the Interclubs. Officially, local groups rather than the ISH were to operate the Interclubs. ${ }^{161}$ Seemingly, the RILU Secretariat initially backed the idea as is evident in its outline for future work in the Caribbean, projecting the Is $\mathrm{H}$ to organise Interclubs in Colon and Panama. ${ }^{162}$

Among the public activities of the ISH in late 1935/early 1936 were its calls for an international anti-war campaign and boycott of the transport of military material to Italy and Japan. The turn-out was rather meagre as the campaigns were concentrated to ports with existing Interclubs, namely Copenhagen, Dunkirk, Esbjerg, Marseille, New York, Rotterdam, Rouen and Stockholm, and liaison persons stationed in Antwerp, Bergen, Calais, Karlshamn, London, Luleå, Narvik, Sundsvall and Trondheim. Top priority was on work in the French and Scandinavian ports as the ISH Illegal Secretariat regarded them to be of highest strategic importance. ${ }^{163}$ By March 1936, however, the IsH leadership must have recognized that its last remaining pillar was a hollow one as

(Berlin: Akademie-Verlag, 2007), 416. On the purges within the Comintern during the Great Terror, see further Arch Getty and Oleg V. Naumov, The Road to Terror: Stalin and the Self-Destruction of the Bolsheviks, 1932-1939 (Yale: Yale University Press, updated and abridged version 2010 [1999]).

161 Bericht über die Internationalen Seeleuteklubs und einige Vorschläge zu ihrer weiteren Tätigkeit, 31.3.1936, 534/5/245, 107-117, RGASPI. The author(s) of the report has not been identified. The document itself was written in Moscow, perhaps by Shelley who worked at that point at the ISH Sovbureau. However, it is likely that the author used material forwarded by the ISH Illegal Secretariat such as excerpts of evaluation reports on the Interclubs in Copenhagen, Rotterdam and Stockholm. Remarks in the beginning of the text points towards the text being at least drafted by Deter and Polano.

162 Anträge zur Arbeit in Zentralamerika, 15.2.1935, 534/5/1037, 26, RGASPI. If the ISH was ever instructed to establish the proposed Interclubs is not known. Anyway, these plans never materialised.

163 Henri [Polano], André [Deter] and Ad [Shelley] to "Cher camarade," Report on activities 1935/36, 534/5/245, 12-34, RGASPI. 
the ISH Illegal Secretariat lacked the financial and organisational capacity to support and monitor the activities of the Interclubs. ${ }^{164}$

The members of the ISH Illegal Secretariat made an evaluation of the situation in March 1936. None of the Interclubs had received any funding from the ISH since 1933 and the national parties had been lukewarm in supporting their activities. Several Interclubs had ceased to exist, notably those in England and the USA. Others were not anymore subordinate to the ISH, such as those in France. Hitherto, the Interclubs had worked in close cooperation with local and national revolutionary trade union opposition groups but as these units had either disappeared or been amalgamated, the remaining Interclubs in Denmark (Copenhagen and Esbjerg), France (Marseille, Rouen and Dunkirk), the Netherlands (Rotterdam) and New York (the Scandinavian Seamen's Club, a new establishment founded in 1935, see below) as well as the liaison offices in Antwerp, Gothenburg, Liverpool, Malmoe, Oslo, San Francisco and Vancouver were to be run as joint establishments by the communists and socialists. Their main task was to focus on work among foreign seamen as well as to propagate for the 'unity' within the trade unions. Therefore, following the example of the Scandinavian unions who established the Scandinavian Seamen's Club in New York, other national maritime unions, such as the English, French and Greek, were to establish liaison offices or branches in foreign ports. ${ }^{165}$

Deter and Polano outlined several scenarios for a future operational superstructure of the Interclubs. Most of the national parties, they claimed, were in favour of transferring all Interclubs to the ITF as part of a joint agreement between the ITF and the ISH. The two comrades rejected the idea, declaring that such a move would inevitably lead to the liquidation of the Interclubs as the ITF and the national unions had little interest of supporting their operations. Instead, they proposed the formation of a new unit, termed 'Society for the support of the international seamen's clubs' (Gesellschaft zur Förderung der internationalen Seeleuteclubs). The idea was to transform the ISH into the named cover organisation, adding to its leadership a group of well-known public persons such as Jensen and Tillon of the legal IS $\mathrm{H}$, the British veteran trade unionist Tom Mann, the German author Theodor Plivier, as well as leading labour union leaders such Bevin, Fimmen and Spence. The crux of the matter was that the plan had to be approved in Moscow. ${ }^{166}$

164 Bericht über die Internationalen Seemannsklubs und einige Vorschläge zu ihrer weiteren Tätigkeit, 31.3.1936, 534/5/245, 107-117, RGASPI.

165 Bericht über die Internationalen Seeleuteklubs und einige Vorschläge zu ihrer weiteren Tätigkeit, 31.3.1936, 534/5/245, 107-117, RGASPI.

166 Bericht über die Internationalen Seeleuteklubs und einige Vorschläge zu ihrer weiteren Tätigkeit, 31.3.1936, 534/5/245, 113-114, RGASPI. 
The new guidelines reflected the establishment of the Scandinavian Seamen's Club in Brooklyn, New York in 1935. Initially, the club closely cooperated with the Norwegian Seamen's and Stokers' Union. However, the Norwegians cut their support when they realised that the club was run by the communists, whereupon the club was supported by the Danish and Swedish unions. ${ }^{167}$ Its intimate connection to the communists was not farfetched. In 1938, Richard Jensen strongly backed the nomination of Georg Hegner as head of the club in Brooklyn. ${ }^{168} \mathrm{~A}$ similar attempt to establish a club for Greek seamen in New York was made in 1936. Polano received a positive answer from 'Angelos' who stated that the Spartacus Educational Club was frequented by Greek seamen as did other workers of Greek nationality. ${ }^{169}$ This was highly interesting news as the Spartacus Educational Club claimed to be a worker's club and attracted the radical segment of the Greek seamen (in comparison to the Greek club run by the Seamen's Church Institute at 25 South Street) and was added on the list on recipients of literature from the ISH. ${ }^{170}$ Moreover, at one point there also existed a section for French seamen at the Clarté office in New York, although not much is known about it apart from a reference to it in the mailing list of ISH publications (see Map 4 and Table 17).

Similar positive news were also heard from Chile, England and South Africa. In spring 1936, a Chilean comrade visited the Is Illegal Secretariat and Deter and Polano convinced him about the idea to set up an Interclub in Valparaiso. The comrade returned to Chile and managed to accomplish his mission, backed by the "progressive segments" among the Chilean seamen. Similar to the Greek club in New York, the establishment in Valparaiso was not an outright Interclub or used the name in public but rather a "centre for the educational and cultural uplift of seamen."171 In Liverpool, a group of dockers and seamen met in mid-November 1936 to launch an Interclub. ${ }^{172}$ In Cape Town,

167 Finn Olstad, "Norsk sjømann eller internasjonal proletar? Striden mellom Norsk sjømannsforbund og den skandinaviske sjømannsklubben 1935-41," Arbeiderhistorie (2010): 101-119.

168 Handwritten letter by Richard Jensen "Kort udlalelse angaaende Georg Hegner Rejse til Amerika," enclosed in 495/208/41, 43-46, RGASPI; German translation of Jensen's letter, dated 5.7.1938, in 495/208/281, 17-19, RGASPI.

169 Letter from "Angelos" to Henry [Luigi Polano], New York 21.9.1936, 534/5/246, 24, RGASPI.

170 "Henry: Einige Bemerkungen," in Konferenz am 18. und 19. Januar 1937. Diskussion zum Referat Henry: Spanien und Berichte aus den einzelnen Häfen bezw. Ländern, no date [ca. January 1937], 534/5/247, 35, RGASPI.

171 "Henry: Einige Bemerkungen," in Konferenz am 18. und 19. Januar 1937. Diskussion zum Referat Henry: Spanien und Berichte aus den einzelnen Häfen bezw. Ländern, no date [ca. January 1937], 534/5/247, 35, RGASPI.

172 Seamen's and Dockers' Group. Meeting held Sunday, October 25th [1936]. [Copy] Received November 17 th, 1936, 534/5/246, 58-59, RGASPI. 


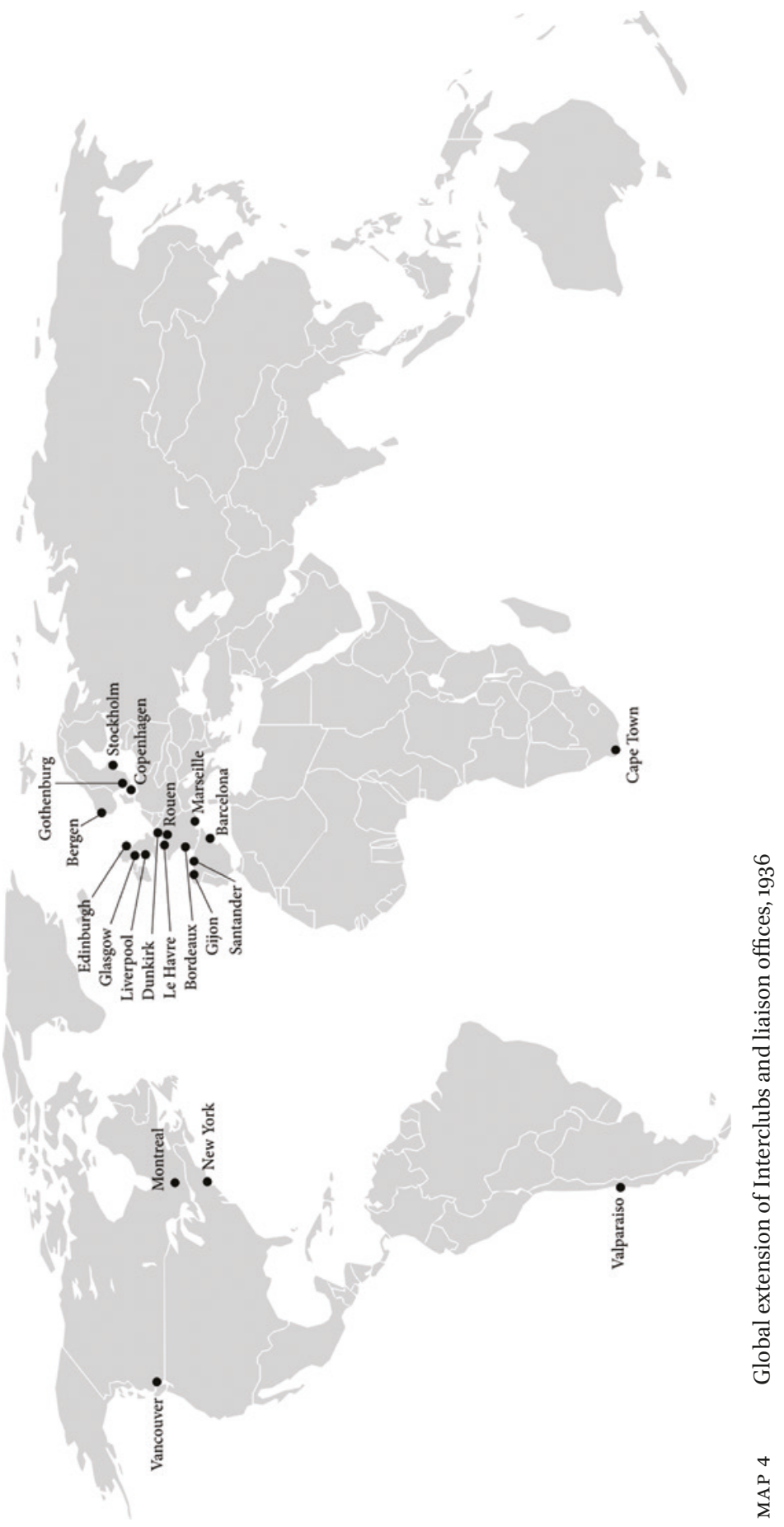




\begin{tabular}{|c|c|c|}
\hline Name & Address & Country \\
\hline [no information] & $\begin{array}{l}\text { Gomez, Cochrane } 55^{2} \text {, } \\
\text { Valparaiso }\end{array}$ & Chile \\
\hline International Seamen's Club & 15/I Gothersgade, Copenhagen & Denmark \\
\hline Havnearbeiders Club & Toldbodgade 16, Copenhagen & Denmark \\
\hline $\begin{array}{l}\text { Trade Union and Workers' } \\
\text { Social Club }\end{array}$ & 11 George Street, Glasgow & Scotland \\
\hline Club International des Marins & $\begin{array}{l}\text { 9, rue de l'Ecluse des Bergues, } \\
\text { Dunkerque }\end{array}$ & France \\
\hline $\begin{array}{l}\text { Synd. des Dockers, Bourse du } \\
\text { Travail }\end{array}$ & Rue de l'Academie, Marseille & France \\
\hline Spartacus Educational Club & 269 W. 25th Street, New York & USA \\
\hline Interklubb & Kronhusgatan 1 B, Gothenburg & Sweden \\
\hline International Seamen's Club & Brunnsgränd 42 tr., Stockholm & Sweden \\
\hline Club de Marins & Calle Ancha No. 1, Barcelona & Spain \\
\hline Scandinavian Seamen's Club & 202 South Broadway, Baltimore & USA \\
\hline Scandinavian Seamen's Club & $\begin{array}{l}1433 \text { Annunciation Street, New } \\
\text { Orleans }\end{array}$ & USA \\
\hline Scandinavian Seamen's Club & $\begin{array}{l}565 \text { Henry Street, Brookly, } \\
\text { New York }\end{array}$ & USA \\
\hline Scandinavian Seamen's Club & 257, West Bute Street, Norfolk & USA \\
\hline Scandinavian Seamen's Club & 23rd Drum Street, San Francisco & USA \\
\hline Scandinavian Seamen's Club & $\begin{array}{l}\text { 903, S. Palos Verdes Street, San } \\
\text { Pedro, Cal. }\end{array}$ & USA \\
\hline Clarté & $\begin{array}{l}148 \text { West } 46 \text { th Street, Room 6o6, } \\
\text { New York }\end{array}$ & USA \\
\hline Union Recreation Center & $3^{2}$ Clay Street, San Francisco & USA \\
\hline
\end{tabular}

SOURCE: LIST OF ADDRESSES OF CLUBS, 2.3.1937, 534/5/247, 71, RGASPI

a "dockers' cell" (Dockerzelle) had been formed after an English comrade had visited the port on a mission to set up an Interclub. The dockers' cell was in contact with Polano and started to receive anti-fascist propaganda material for distribution among German and Italian crews. ${ }^{173}$

173 "Henry: Einige Bemerkungen," in Konferenz am 18. und 19. Januar 1937. Diskussion zum Referat Henry: Spanien und Berichte aus den einzelnen Häfen bezw. Ländern, no date 
Luigi Polano was called back to Moscow during the latter half of 1936 and resumed his work at the ISH Sovbureau (or what was left of it). At this point, the IS H Sovbureau seems to have shrunk into a liaison office for the dissemination of material in the Pacific while the Is H Illegal Secretariat in Paris covered the Atlantic. The contours of the operations of the ISH in fall 1936 is grasped in a letter from comrade "Jack" of the "Bureau du Pacific" in Los Angeles to Polano. Jack's office was the PPTUs (or what was left of it) and he informed about the work among Japanese and Chinese seamen. The assistance of the ISH was highly esteemed, Jack noted, as the Japanese printed matters by the PPTUS were distributed through the global nodes of the ISH (i.e., the remaining Interclubs). "Before the Japanese were watching all ships from US. Now they have to worry about ships from all countries and they are very much alarmed. They really imagine that tons of literature gets in every month. The little incidence reported at Cape Town is valuable especially because now they realise that there is not a single important port that is 'safe' from dangerous thoughts." In similar ways did agitation material reach Chinese seamen, including the PPTUs publication the "Chinese Seamen", mainly distributed via Liverpool. ${ }^{174}$

\section{2 "They Shall not Pass!": Spain and the ISH}

Much has been written about the involvement of the Comintern and especially the Soviet Union in the Spanish Civil War. ${ }^{175}$ The international solidarity campaigns in support of the victims of the Spanish Civil War as well as the International Brigades are well documented and analysed, both from a national, transnational and international perspective. Although the Ethiopian conflict had elicited a global anti-fascist consciousness regardless of skin colour, the Great Powers had prevented concrete actions to fight Italian imperialism. For people activated and radicalised during the Ethiopian conflict, the civil war in Spain became a new opportunity to

[ca. January 1937], 534/5/247, 35, RGASPI. I have not been able to trace the correspondence from the docker's cell in Cape Town.

174 Lettre du comr Jack, responsible du Bureau du Pacifique (Los Angeles), "Dear Henry," 10.11.1936, 534/5/246, 53, RGASPI.

175 Among others, E.H. Carr, The Comintern and the Spanish Civil War (London: Pantheon Books, 1984); Svetlana Pozharskaya, "Comintern and the Spanish Civil War," Ebre 38, no. 1 (2003): 47-56; Stanley G. Payne, The Spanish Civil War, the Soviet Union, and Communism (New Haven \& London: Yale University Press, 2004); Daniel Kowalsky, Stalin and the Spanish Civil War (New York: Columbia University Press, 2004); Lisa A. Kirschenbaum, International Communism and the Spanish Civil War: Solidarity and Suspicion (New York: Cambridge University Press, 2015). 
manifest their proletarian solidarity by volunteering in the pro-Republican International Brigades. ${ }^{176}$

The decision to set up the International Brigades had been made by the Executive Committee of the Comintern in September 1936. The recruitment was to be carried out by the national communist parties. As the European governments, including the German and Italian, as well as the Soviet Union, had signed a non-intervention treaty to prevent escalation of the conflict on 24 August 1936, the enlistment to the International Brigades became illegal. For example, the Danish Parliament passed a law prohibiting volunteers from going to Spain on February 25, 1937; in Sweden, a similar ban was adopted on March 3, in Norway on March $17 \cdot{ }^{177}$

The nationalist coup attempt and the subsequent civil war in Spain became the launching point for the first unified international anti-fascist solidarity campaign. The initiative was taken by the World Committee on War and Fascism on 30 July 1936 when it sent a telegram to the Labour and Socialist International to call for joint actions. The World Committee was formally nonpartisan, but advocated the idea of the People's Front as part of the defence against fascism and Nazism. However, the social democrats regarded the World Committee as a disguised communist organisation and were initially suspicious of plans to set up a coordination committee for international humanitarian aid for Spain. The initiative was discussed during late summer before the initiators succeeded in launching the so-called Coordination Committee at a conference on 7-11 September in Paris. In parallel with this initiative, the Labour and Socialist International and the International Federation of Trade Unions set up the 'Spanish committee of the International Solidarity Fund' as part of the Matteotti Fund. The two committees organised relief and humanitarian aid to Republican Spain until 1939; the International Solidarity Fund distributed humanitarian aid worth approximately 50 million French franc, while

176 David Featherstone, "Black internationalism, Subaltern Cosmopolitanism, and the Spatial Politics of Antifascism," Annals of the Association of American Geographers 103, no. 6 (2013): 1406-20; David Featherstone, "Black internationalism, international communism and anti-fascist political trajectories: African-American volunteers in the Spanish Civil War," Twentieth Century Communism - A Journal of International History 7 (2014): 940; Gleb J. Albert, “'To help the Republicans not just by donations and rallies, but with the rifle": Militant solidarity with the Spanish Republic in the Soviet Union, 1936-1937," European Review of History: Revue européenne d'histoire 21, no. 4 (2014): 501-518.

177 Claes-Göran Jönsson, "SKP och den svenska spanienrörelsen," Arkiv för arbetarhistoria 4 (1973): 9; Svend Rybner, "Fairyland - Nordic Communism and the Spanish Civil War 19361939," in Red Star in the North: Communism in the Nordic Countries, eds. Åsmund Egge and Svend Rybner (Stamsund: Orkana Akademisk, 2015), 228-229. 
the Coordination Committee's contribution amounted to about 800 million French franc. ${ }^{178}$

At the same time as the conflict escalated in Spain, the purges in the Soviet Union culminated in the Moscow trial in August 1936. Foreign communists were also affected. ${ }^{179}$ Concerns spread among maritime transport workers: why, what was going on? Socialists and social democrats raised critical questions, the communists were at loss. ${ }^{180}$

The ISH never launched a campaign to support of the Spanish government or to recruit volunteers for the International Brigades. It simply did not have the authorisation to do so as agitation and propaganda work among the maritime transport workers had been transferred to the communist parties and their sea cells. However, due to the ban on the recruitment of volunteers, this had to be conducted as a covert mission. Key centres for mobilising volunteers were the Interclubs where information and recruitment actions could be carried out outside the authorities' supervision and control. Although the ISH did not any longer control the few remaining Interclubs, the Is $\mathrm{H}$ Illegal Secretariat initially tried to coordinate their activities in tandem with those of the local sea cells and communist parties. ${ }^{181}$

The clandestine recruitment campaign on the waterfront must have benefitted from anti-Nazi demonstrations in July. Called by the IsH Secretariat to protest against the death sentence of Etkar André by the Hamburg court, demonstrations were organised by the communists in Belgium, Britain, Denmark, France, Iceland, Norway, and Sweden. ${ }^{182}$

The radicalisation and the increased critical global awareness among maritime transport workers can be exemplified by two texts published in the Swedish journal Hamn- och sjöproletären in 1936. In the first, the author lamented that violence and destruction had triumphed in Ethiopia. Fascism meant nothing but war, and Fascist Italy had violated the rules of the war when using poison

178 Van Goethem, The Amsterdam International, 218; Bertel Lundvik, Solidaritet och partitaktik. Den svenska arbetarrörelsen och spanska inbördeskriget 1936-39 (Uppsala: Acta Universitatis Upsaliensis, 1980): 47-50, 104-105.

179 William J. Chase, Enemies Within the Gates? The Comintern and the Stalinist Repression, 1934-1939 (New Haven: Yale University Press, 2001). See further the discussion on the "topography of terror" in Karl Schlögel, Terror und Traum: Moskau 1937 (München: Carl Hanser Verlag, 2008).

180 “Varför?," Sjömannen 9 (1936): 265-268.

181 "Spanish Civil War and the Seafarers and Dockers," https://scwharbour3639.wordpress. com/over/, checked 2.3.2018.

182 "Edgar André zum Tode verurteilt!" Informations- und Pressedienst der ISH Nr 70, 16. juli 1936, filed in 539/3/56o, 217-218, RGASPI. 
gases in its warfare. The lesson of the defeat in Ethiopia was that the fight against fascism required a united front and unified action. ${ }^{183}$ Just as fascism seemed to celebrate its greatest triumph, the second text was published - the strike of the Spanish seamen had ended in total victory for the workers! None of the previous strikes had succeeded in forcing the shipowners and capitalists to capitulate and agree to revolutionary improvements for the seamen: 8-hour workday for all occupational groups in the Spanish merchant fleet and general increase of salaries. In addition, the crew was given the right to control the use of food allowances. Hiring agencies were regulated and uniform mustering expeditions would be set up in each port. Overtime work would be paid, paid holidays were introduced. Sensational was the clause that shipowners who laid up ships were obliged to hire security guards on a daily basis for surveillance and other work on the laid up vessels. These security guards would consist of mariners who were over 45 years old. ${ }^{184}$ If Ethiopia emerged as the antithesis in the fight against fascism, the Spanish Second Republic materialised as the mariners' Promised Land. The nationalist coup d'état in July 1936 was therefore nothing but a combined fascist-capitalist attack on the working class.

The maritime transport workers and their unions supported Republican Spain at an early stage. So did the ISH Secretariat, which assigned itself the role as a channel for disseminating news about Spain. Already at the end of August 1936, the ISH Secretariat published a plea for solidarity with the Spanish people. ${ }^{185}$ News and information about anti-fascist actions conducted by the Interclubs in support of Republican Spain followed during autumn although the role of the ISH Secretariat as instigator of the activities is unclear. ${ }^{186}$

\subsection{The Last Mustering: Paris, January 1937}

Representatives of the Interclubs gathered in Paris in January 1937 to discuss the campaign in support for Republican Spain, the illegal recruitment of volunteers to the International Brigades, and the future work of the Interclubs.

\footnotetext{
183 "Första etappen i Mussolinis erövringskrig," Hamn- och sjöproletären 6, no. 5 (1936): 7.

184 "Stor seger för spanska sjöfolket," Hamn- och sjöproletären 6, no. 6 (1936): 8.

185 "Solidarité avec le peuple Espagnol!," Service d'information et de Presse de l'I.M.D. No. 76, 29.8.1936, 534/5/246, 14-17, RGASPI.

186 Only a few issues of the autumn 1936 Is H Bulletin are archived, all of them containing information of actions in support of Republican Spain: Service d'information et de Presse de l'I.M.D., No. 77, 3.9.1936, 534/5/246, 21-23; Service d'information et de Presse de l'I.M.D., No. 81, 8.10.1936, 534/5/246, 26-28; Service d'information et de Presse de l'I.M.D., No. 82, 15.10.1936, 534/5/246, 29-32; Service d'information et de Presse de l'I.M.D., No. 90, 18.11.1936, 534/5/246, 33-35; Service d'information et de Presse de l'I.M.D., No. 93, 3.12.1936, 534/5/246, 6o-62, RGASPI.
} 
Present were comrades from Belgium, England, France, Spain and Sweden. Whereas the recruitment of volunteers had been a success, the coordination of boycotting ships bound to Spain had hitherto failed. The main challenge was the lack of information about the cargo and destination of a vessel: Was it loaded with war material destined for the rebels? Adolf Deter and Luigi Polano (the latter one seems to have arrived from Moscow for the conference) emphasised the importance of continuously providing the ISH Secretariat with information on various actions so that it could present them in its bulletin as ways of combatting fascism in practice. If the destination of a ship was unclear, the ISH Secretariat was to be immediately notified as it claimed to have the capacity to determine its route. Besides, Deter urged the comrades to ensure that the actions of the Interclubs were strictly legal and were sanctioned by the national unions. ${ }^{187}$

The second item on the agenda was the transformation of the Interclubs into 'centres for the cultural and political education of maritime transport workers. Assessing the operational basis of the few remaining units, Deter and Polano realised that their existence was doomed. Outright Interclubs had ceased to exist in England, France and Norway. Work in Dunkirk, Marseille, Rouen and Liverpool was conducted by the communist fractions and members within the unions, activities in the Norwegian ports had collapsed, as there were only a few members left. Apart from Antwerp, Dunkirk and Marseille, work among foreign seamen was negligible, and the network of liaison persons on board the ships had more or less collapsed. ${ }^{188}$ The Interclub in Rotterdam had been transformed into a "cultural club" (Klub voor culurele Ontwikkeeling en Outspanning voor Transportarbeiders), that in San Francisco into a "Union Recreation Centre", and the club in Vancouver was the "Bureau of the Seafarers' Industrial Union."189 In Greece, the quasi-fascist Métaxas government had crushed the communist fraction within the Greek Seamen's Union. Polano had tried to launch an international campaign to support the extra-territorial radical groups of Greek seamen in Antwerp, Buenos Aires, Cardiff, Marseille and Rosario but its outcome has left few (documented) traces. ${ }^{190}$ The Interclub

187 Konferenz am 18. und 19. Januar 1937. Diskussion zum Referat Henry: Spanien und Berichte aus den einzelnen Häfen bezw. Ländern, no date [ca. January 1937], 534/5/247, 5-11, 13, 20, 25, RGASPI.

188 Konferenz am 18. und 19. Januar 1937. Diskussion zum Referat Henry: Spanien und Berichte aus den einzelnen Häfen bezw. Ländern, no date [ca. January 1937], 534/5/247, 10-13, 23, RGASPI.

189 Service d'inormation et de Presse de l'I.M.D. No. 81, 8.10.1936, 534/5/246, 26-28, RGASPI.

190 Lotti[?] to Henry, 4.11.1936; Ménégos, Secretaire, Union des Marins due Grève (N.E.E.) to Secrétariat de l'ImD, Piraeus, 10.11.1936; and Henri [Luigi Polano] to NN, 23.11.1936, 534/5/ 
in Marseille, the previous main agitation centre for work among Greek and Italian seamen, had shrunk into a club for French communist mariners. ${ }^{191}$ On the other hand, the German "Aktivgruppe" (action group) in Antwerp claimed to be in contact with 150 out of 1,000 German vessels. ${ }^{192}$

The only really good news was the establishment of a new Interclub in Barcelona. The victorious strike of the Spanish seamen in 1936 had been led by a 'unity committee'. It had set up the Interclub immediately after the strike and started its operations in a new building on New Year's Day 1937. Large signs and billboards in the harbour area directed the seamen to the club. The premises must have been impressive and resembled those in Hamburg and Leningrad. The club had at its disposal nine rooms on the ground and first floor of the building, including a library, a reading room, a meeting hall, a bar with twelve tables, a leisure room with a billiard table, an assembly hall, and a gym. The club was run by a collective leadership, most of whom were communists. ${ }^{193}$

Commenting the fate of the remaining Interclubs, comrade Webster, the secretary of the seamen's and dockers' group in Liverpool, supported their transformation into "cultural centres" and proposed that the ISH should send an instructor to supervise this process. The new centres, he suggested, were to be called 'Centres of Maritime Transport Workers' as the existing name, International Seamen's Clubs, had negative connotations among noncommunist maritime workers. His proposal was met with general acclamation. Comrade Nilsson from Sweden informed that the clubs in Gothenburg and Stockholm were already in the process of reorganisation, comrades Maurice from Le Havre and Ali from Rouen noted that the local groups planned to set up cultural centres at the local premises of the seamen's union. Webster also urged to focus on engaging women - interestingly, for the first time ever was this topic on the agenda of a meeting. "We have hitherto not realised the

$246,50-51,55^{-} 57$, RGASPI. It is likely that Ménègos' letter - or a copy of it - was forwarded to Polano in Moscow; the recipient of Polano's letter was probably someone in Marseille.

191 Konferenz am 18. und 19. Januar 1937. Diskussion zum Referat Henry: Spanien und Berichte aus den einzelnen Häfen bezw. Ländern, no date [ca. January 1937], 534/5/247, 10-13, RGASPI.

192 Konferenz am 18. und 19. Januar 1937. Diskussion zum Referat Henry: Spanien und Berichte aus den einzelnen Häfen bezw. Ländern, no date [ca. January 1937], 534/5/247, 31, RGASPI. On the German Aktivgruppe in Antwerp, see further Nelles, Widerstand und internationale Solidarität, and Knüfken, Von Kiel bis Leningrad.

193 Konferenz am 18. und 19. Januar 1937. Diskussion zum Referat Henry: Spanien und Berichte aus den einzelnen Häfen bezw. Ländern, no date [ca. January 1937], 534/5/247, 27-29, RGASPI. 
important role women have conducted in the Interclubs and in our work on the waterfront," Webster noted. ${ }^{194}$

The ISH Illegal Secretariat decided to transform the Interclubs into cultural centres as an outcome of the discussions at the January 1937 conference. A few of them, such as the Copenhagen Interclub was to be liquidated and to be replaced by a reading hall run by the Danish maritime unions. The club in Gothenburg was to be transformed into a unity club for all maritime transport workers; the club in Stockholm was to be fused with the social democratic seamen's club. ${ }^{195}$

\subsection{Maritime Transport Workers and Militant Anti-fascism}

Joining the International Brigades was an expression of militant anti-fascism. A substantial number of the recruits were maritime transport worker, among others 800 of the 3,000 US American volunteers were seamen, ${ }^{196} 120$ out of 659 Swedes, ${ }^{197} 82$ out of 152 Norwegians and one-third of the Danish and Finnish volunteers. ${ }^{198}$ Communist mariners constituted a large, if not the largest, segment among the volunteers.

Richard Jensen in Denmark engaged in a different form of militant antifascism. Auguste Dumay together with Émile Sellon organised the FranceNavigation freight company in April 1937 as a cover for the illegal transport of war materials to the Republican government. ${ }^{199}$ On behalf of the Comintern technical bureau in Paris, Jensen officially chartered or bought nine steamers, officially in the name of the Spanish government, and staffed them with reliable comrades who had been members of the Danish RFo to smuggle in

194 Konferenz am 18. und 19. Januar 1937. Diskussion zum Referat Henry: Spanien und Berichte aus den einzelnen Häfen bezw. Ländern, no date [ca. January 1937], 534/5/247, 24-25, 33-34, 36-37, RGASPI.

195 Die Klubs in Skandinavien, no date [ca. late January 1937], 534/5/247, 82-84, RGASPI. The author of the report was probably Adolf Deter; it must have been written before 1.2.1937 as the author refers to the liquidation of the Copenhagen Interclub "to take place on 1.2." (wird am 1.2. liquidiert).

196 Nelson, Workers on the Waterfront, 3o; Albert Vetere Lannon, Second String Red: The Life of Al Lannon, American Communist (Lanham, Boulder, New York and Oxfords: Lexington Books, 1999), 71.

197 Lundvik, Solidaritet och partitaktik, 122-123, 137-138, 142.

198 See further Morten Møller, De glemtes hæer - danske frivillige i den spanske borgerkrig (København: Gyldendal, 2017). Arve Kvaløy, Norske frivillige i den spanske borgerkrig norsk humanitær og militær hjelp til republikken 1936-39, MA thesis, Oslo University, 1996; Jyrki Juusela, Suomalaiset Espanjan sisällissodassa (Jyväskylä: Atena Kustannus OY, 2003).

199 See further Dominique Grisoni \& Gilles Hertzog, Les brigades de la mer (Paris: Éditions Grasset et Fasquelle, [1979] 2012). 
weapons and military supplies to Republicans. Officially banned by the international non-intervention agreement of August 1936, the Soviet Union and the national communist parties were not to be linked to these clandestine operations. The consignments to the Spanish government were therefore to be kept secret and arranged under cover of some type of legal activity. ${ }^{200}$ Jensen's company, which came to be known as the Jensen Shipping Company, was officially owned by the Spanish state and handled the transportation of weapons purchased in Denmark, Sweden, Finland, Estonia, Latvia, Romania and Mexico. ${ }^{201}$ British intelligence uncovered his operations in August 1937 when his camouflage freight company Franaviga Shipping Company bought the SS Tusker. Under the name Lola, the steamer was registered in Panama and went from Copenhagen to Constanza in Romania where it was scheduled to pick up a load of Polish weapons officially destined to Greece. However, the Romanian authorities doubted the freight order and when it became clear that the cargo was on its way to Spain, the permit was revoked. ${ }^{202}$

Jensen's operations had no links to the ISH. His shipping organisation does not figure in the Gestapo material that painted the ISH as a sabotage organisation or in their reports on the Wollweber League. Neither are there any references on him or his shipping organisation in the few remaining reports from the ISH (Illegal) Secretariat in the autumn of 1936 and the winter of 1937. Tellingly, there was no representative from Denmark at the January 1937 meeting in Paris.

\section{$5 \quad$ Liquidation}

The last chapter of the ISH was written in Moscow. The U-turn of the Comintern, the transition to and implementation of the 'Popular Front'-tactics had made the RILU and its organisations redundant. The disbandment of the RILU started in $1936 .{ }^{203}$ In early 1937, the leadership of the Comintern started to discuss the fate of the ISH. Polano was ordered to comply a report on the activities and outreach of the ISH. Noting that all legal sections of the ISH had merged with parallel organisations in the various countries, the Is $\mathrm{H}$ at present

200 Nørgaard, Krigen før krigen, 17-20; Nørgaard, Richard Jensen, 8o. Nørgaard claims that Jensen was closely cooperating with Ernst Wollweber but this is doubted by Borgersrud, Die Wollweber-Organisation, 86-87.

201 Borgersrud, Die Wollweber-Organisation, 86; Tortzen, En sømand han maa lide, 264.

202 Minutes, 30.8.1937, Richard Jensen personal file, KV 2/2158, TNA.

203 Tosstorff, The Red International of Labour Unions, 693-70o. 


Country Port

$\begin{array}{ll}\text { Algeria } & \text { Oran } \\ \text { Canada } & \text { Vancouver } \\ \text { Chile } & \text { Valparaiso } \\ \text { Denmark } & \text { Copenhagen } \\ \text { France } & \text { Bordeaux, Le Havre, Marseille, Rouen, Dunkirk } \\ \text { Netherlands } & \text { Rotterdam } \\ \text { Norway } & \text { Haugesund } \\ \text { Spain } & \text { Barcelona, Gijon, Santander } \\ \text { South Africa } & \text { Cape Town } \\ \text { Sweden } & \text { Gothenburg, Helsingborg, Stockholm } \\ \text { United Kingdom } & \text { Cardiff, Glasgow, Liverpool } \\ \text { USA } & \text { Baltimore, New Orleans, New York, Norfolk, } \\ & \text { Philadelphia, San Francisco, San Pedro }\end{array}$

SOURCE: L'I.M.D. ET L'UNiTÉ SYNDICALE (NO DATE, STAMP:13.IV.1937), 534/5/247, 172180, RGASPI

did not have any real organisation. What remained was its (illegal) secretariat in Paris and a network of liaison offices, Interclubs and 'cultural centres' in 25 ports, see Table 18.

Only three Interclubs were monitored by the ISH, namely those in Dunkirk, Gothenburg and Stockholm. Three of the units were controlled by the unions or local 'unity' groups (“Clubs syndicaux:" Barcelona, Copenhagen, Le Havre, and San Francisco), while those in Glasgow and Liverpool as well as the Scandinavian Seamen's Clubs in the USA were autonomous clubs. The units in Antwerp and Rotterdam as well as the Greek Seamen's Club in New York were reading halls monitored by the IsH, those in Haugesund, Helsingborg and Rouen were reading halls controlled by the unions, whereas the unit in Marseille constituted of the communist seamen's cell. ${ }^{204}$

Following Polano's assessment, the ECCI charged RILU General Secretary Lozovsky to prepare a memorandum on the future activities of the ISH. ${ }^{205} \mathrm{In}$

204 [Polano,] L'I.M.D. et l'Unité Syndicale, no date [stamp: 13.4.1937], 534/5/247, 145-18o, RGASPI.

205 Protokoll Nr 5 der Sitzung der Gewerkschaftsdreierkommission des Sekretariats des E KKI am 21.3.1937, 495/18/499, 29, RGASPI. 
line with earlier considerations of the ISH Illegal Secretariat, Lozovsky suggested to quietly liquidate the IS $\mathrm{H}$ and replace it with a new unit called 'Bureau for the Support of the Culture and Educational Activities of Among Marine Workers'. The Bureau was to be under direct control of the ECCI and was projected to support the work of the parties and communist trade union fractions in the Interclubs and the ITF-affiliated unions. Its main task was to help the mobilisation of maritime transport workers for the struggle against fascism and war, for support to the Spanish Republic and the Spanish people, for the defence of the Soviet Union, and for achieving unity within the ranks of the IT F. Globally, the Bureau was to extend its network of International Seamen's Clubs "in the ports which are of big importance for the point of view of the foreign seamen who come there (Oran, Algiers, Alexandria, Vera Cruz, Sydney, Cape Town, Buenos Aires, Rosario, etc.)." The Bureau was to come out openly as an editorial office of the weekly bulletin termed "Information Bulletin for Seamen and Port Workers," to be published in English, French, German and Spanish. ${ }^{206}$

The projected Bureau was never established. The ECCI rejected Lozovsky's plan on 23 June. ${ }^{207}$ Two days later, Comintern Secretaries Florin, Gottwald, Marty and Pieck voted to liquidate the $\mathrm{ISH}^{208}$ the ECCI confirmed the decision on 27 June $1937 .{ }^{209}$ No official announcement, no public declarations, the shutdown of the Is $\mathrm{H}$ was a quiet affaire.

Polano's assessment directly affected Adolf Deter's position. He certainly had backed the transformation of the IsH into an information bureau, perhaps even pushed for it as is indicated in his and Polano's reports from 1936. However, Polano's report to the Comintern as well as the instructions of the ECCI for Losvosky seemed to have propelled a new audit of the accounts of the IS H. What followed is unclear. Boris Ginzburger claimed that Deter approached him on 1 April 1937 and asked him to return the hidden box containing the invoices of the ISH. Ginzburger refused to do, stating that he would only do so

206 Protokoll Nr 6 der Sitzung der Gewerkschaftsdreierkommission des Sekretariats des E KKI am 15.5.1937, 495/18/499, 1, RGASPI; Internal memorandum by the ECCI Secretariat on work among the seamen, 23.6.1937, 495/18/1206, 10-14, RGASPI; Secretariat des EKKI, Protokol Nr. 155, 27.6.1937, 495/20/857, RGASPI.

207 Internal memorandum by the ECCI Secretariat on work among the seamen, 23.6.1937, 495/18/1206, 10-11, RGASPI.

208 Fliegende Abstimmung, 25.6.1937, Beschlussentwurf betr. Internationale der Seeleute und Hafenarbeiter, 495/18/1206, 18, RGASPI.

209 Protokoll (A) Nr 155 des Sekretariats des EKKI am 27.6.1937, 495/18/1206, 1; EKKI 23.6.1937, entgültiger Text vom EKKI am 27.6.1937 bestätigt, 495/20/857, 3-5, RGASPI. 
if orders came directly from the RILU headquarters. Deter was furious; perhaps an indication that he had been accused for cooking the books? ${ }^{210}$

If Deter was part of a new internal investigation of the ISH in spring 1937 is not known. His personal file at the Comintern Archives does not contain any information for him misusing or embezzling funds. Any accusations are lacking in his autobiographies although this is not surprising as he wrote them in 1949 and 1951 and he might have deliberately omitted such information. However, his correspondence to Moscow in 1937 reveals that he had not been informed about the liquidation of the ISH. Instead, he seems to have been confident of the acceptance of the plan of transforming the ISH into a special information bureau for directing the activities of the former Interclubs. In April 1937, he asked Polano to prepare a series of brochures to be sent to the former Interclubs on the Bolshevik revolution as well as on the danger of fascism. ${ }^{211}$ In May, he informed Polano about the plan to set up a Scandinavian seamen's club in Shanghai, what he needed was contact information of the Chinese seamen's and docker's unions to be forwarded to the Scandinavian comrades. However, his letter of May 1937 signalled anxiety about what to do: "I have not received from you any news for the last 8 months. [...] Please, write me soon so that I can send you further information about our movement in England."212 A few weeks later, he forwarded copies of letters he had received from the USA. ${ }^{213}$ Moscow remained silent, no news from Polano. In June, Deter's anxiety turned into distress: "Dear brother Henry, we have written to you several times in recent times ..." (Lieber Bruder Henry, ich habe dir in der lezten Zeit wiederholt geschrieben ...) Deter's letter was coded and personal, similar to the others he sent to Moscow during the latter half of 1937, some of them addressed to "Henriette" and "Maria" as if he was writing to a girl friend or female relative. Deter had expected Polano to return to Paris "to spend your holiday with us,"214 i.e., to continue his work at the IsH Illegal Secretariat; he himself was not in a good shape and had been ill but now recovered (perhaps an indication of the internal investigation during spring 1937?) yet faced a new personal setback as he was unemployed. "I previously wrote to you about the

210 Letter by Boris Ginzburger, Paris 29.3.1937, 495/221/425, 82-83, RGASPI. Interestingly, the dating of Ginzburger's letter and his claim that Deter approached him on 1 April are confusing, perhaps this paragraph was a postscript?

211 André to Henry, 25.4.1937, 534/5/247, 181, RGASPI.

212 Ich weiss wirklich nicht, was ich machen soll, da ich von dir seit 8 Wochen ohne jede nachricht bin; André to "W.G." [Werte Genossen], add: An Alexander fuer Henri, 10.5.1937, 534/5/247, 204, RGASPI.

213 André to Henry, 24.5.1937, 534/5/247, 224, RGASPI.

214 [...] dass du mich auch in diesem Jahr zu deinem Urlaub wieder besuchen wirst. 
pitiful state of affairs of our company [i.e., the IsH]. The situation turned worse during the last weeks. Work was at first down-scaled to a minimum to keep the personnel, then salaries were cut and now we have all been sacked."215 Deter worried about how to take care of his family as money was short for paying rent and social securities, buying food for the children and paying school fees. "I virtually have any Sous left." Was it a personal crisis or did he describe the impending collapse of the remaining activities of the ISH? "Please write to our uncle and ask him to help us." Was the "uncle" Solomon (Alexander) Lozovsky, were the "children" the (former) Interclubs?216

Polano did not come to Paris to spend his "holidays" with Deter. In September, Deter was desperate. Still no news from "Henriette", Deter was extremely worried (grosse Sorgen) about the fate of the "family" and the "company". The "company" was almost defunct, as its "turnover" had declined drastically during the last months. Deter had been without "salary" for four months and was unable to pay his "bills". The "children" were with their "grandparents", Deter had not been able to give them anything. "My uncle had not been in contact for years although I have written to him several times."217

News from Moscow finally reached Deter in early in October 1937. Probably contacted by Polano, Deter was finally informed about the liquidation of the ISH. "This was not a very positive news," Deter replied to "Maria", and complained that he did not know what to do next. Neither the "uncle" nor the "first mate" (Steuermann) had replied to his letters and Deter begged "Maria" to inquire from them about his fate. Deter had tried to keep the "company" running all the time by borrowing money to pay for the expenses but now, as the "company" was to be dissolved, he would face a grave financial crisis. Was the "first mate" Polano who, Deter claimed, knew him very well and certainly would understand his situation? ${ }^{218} \mathrm{~A}$ few months later, Deter received a letter from Polano who confirmed the liquidation of the ISH and informed Deter about his task to wind up the "company." Similar instructions had been sent to "Gaston" by the "uncle" (Lozovsky?). Deter immediately commenced with closing the office and disposing its furniture to cover at least part of his expenses. ${ }^{219}$ Deter was then transferred to coordinate the illegal trade union

215 Ich hatte dir ja schon einmal geschrieben dass es bei unserer Firma sehr schlecht aussieht mit der Arbeit. In den lezten Wochen ging es immer mehr bergab. Erst wurde die Arbeit eingeschränkt um Entlassungen zu vermeiden, dann wurde das Gehalt gekürzt und nun sind wir alle entlassen worden.

216 André to "Lieber Bruder Henry," 21.6.1937, 534/5/247, 231, RGASPI.

217 André to "Liebe Henriette," 9.9.1937, 534/5/247, 231, RGASPI.

218 André to "Liebe Maria," 5.10.1937, 534/5/247, 239, RGASPI.

219 André to "Liebe Henriette," 6.12.1937, 243, RGASPI. 
operations in Germany. ${ }^{220}$ In March 1938, Comintern Secretary General Georgi Dimitrov sent Bohumir Smeral to switch off the lights at the ISH office in Paris and finalise its liquidation..$^{221}$

220 Lebenslauf Gustav Adolf Deter, Abschrift 27.9.1950, 495/205/188, 64, RGASPI.

221 [Dimitrov,] Anweisung für Gen. Smeral, 20.3.1938, 495/73/76, 6, RGASPI. 